OXFORD

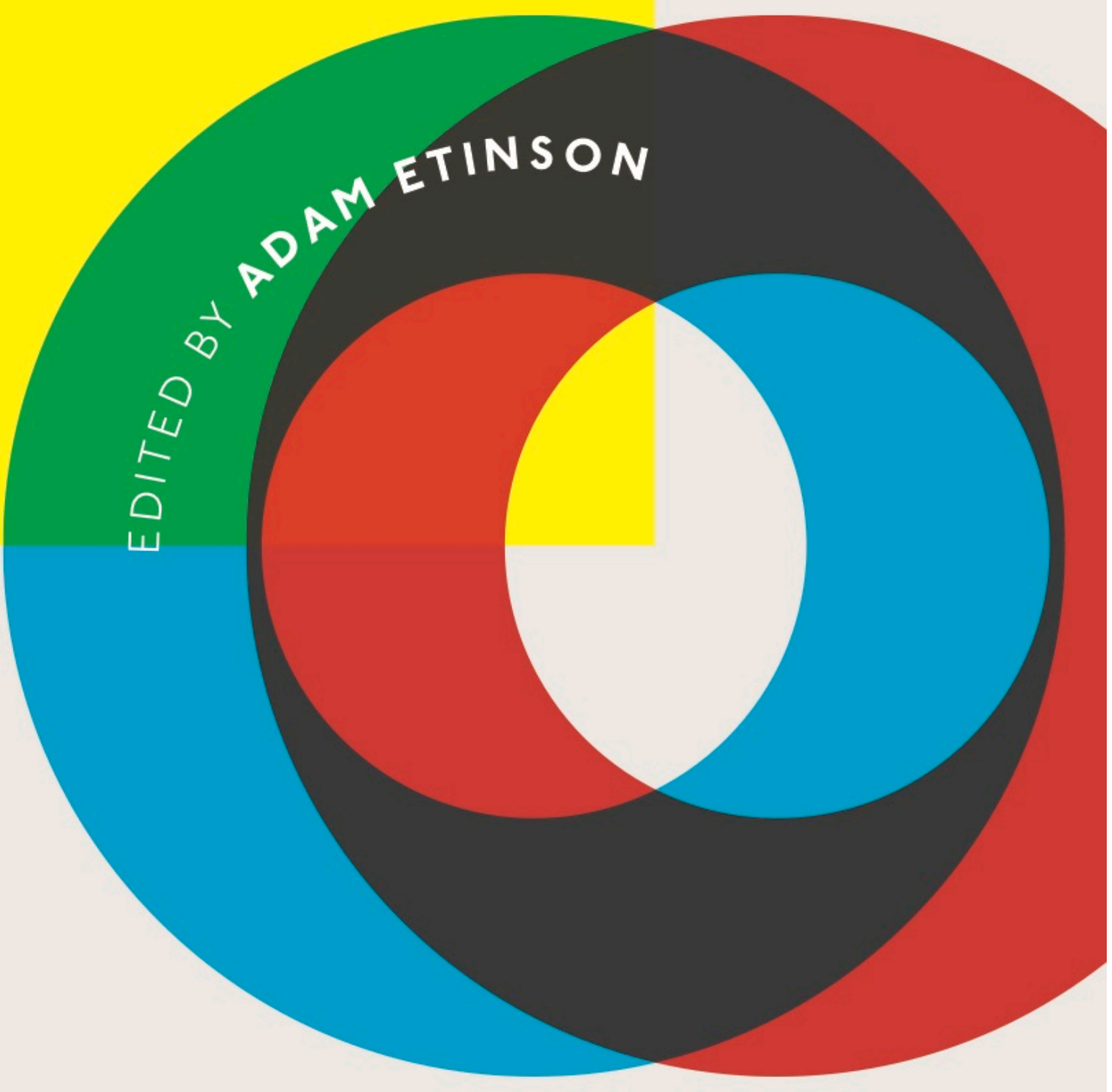

HUMAN RIGHTS MORAL OR POLITICAL? 


\section{Human Rights: Moral or Political?}

EDITED BY

Adam Etinson 


\section{OXFORD}

\section{UNIVERSITY PRESS}

Great Clarendon Street, Oxford, OX2 6DP,

United Kingdom

Oxford University Press is a department of the University of Oxford.

It furthers the University's objective of excellence in research, scholarship, and education by publishing worldwide. Oxford is a registered trade mark of Oxford University Press in the UK and in certain other countries

(c) the several contributors 2018

The moral rights of the authors have been asserted

First Edition published in 2018

Impression: 1

All rights reserved. No part of this publication may be reproduced, stored in a retrieval system, or transmitted, in any form or by any means, without the prior permission in writing of Oxford University Press, or as expressly permitted by law, by licence or under terms agreed with the appropriate reprographics rights organization. Enquiries concerning reproduction outside the scope of the above should be sent to the Rights Department, Oxford University Press, at the address above

You must not circulate this work in any other form and you must impose this same condition on any acquirer

Published in the United States of America by Oxford University Press 198 Madison Avenue, New York, NY 10016, United States of America

British Library Cataloguing in Publication Data

Data available

Library of Congress Control Number: 2017954187

ISBN 978-0-19-871325-8

Printed and bound by

CPI Group (UK) Ltd, Croydon, CR0 4YY

Links to third party websites are provided by Oxford in good faith and for information only. Oxford disclaims any responsibility for the materials contained in any third party website referenced in this work. 


\section{Contents}

Contributors $\quad$ ix

Introduction 1

Adam Etinson

\section{Part I. The Relevance of History}

1. Rights, History, Critique

Martti Koskenniemi

1.1 Doing Without an Original: A Commentary on Martti Koskenniemi

Annabel Brett

2. Human Rights in Heaven

Samuel Moyn

2.1 Philosophizing the Real World of Human Rights:

A Reply to Samuel Moyn

John Tasioulas

2.2 Genealogies of Human Rights: What's at Stake?

Jeffrey Flynn

\section{Part II. The Orthodox-Political Debate}

3. Human Rights: A Critique of the Raz/Rawls Approach

Jeremy Waldron

3.1 On Waldron's Critique of Raz on Human Rights

Joseph Raz

4. Assigning Functions to Human Rights: Methodological Issues in Human Rights Theory

James W. Nickel

4.1 On Being Faithful to the "Practice": A Response to Nickel Adam Etinson

5. Beyond the Political-Orthodox Divide: The Broad View Andrea Sangiovanni

5.1 Human Rights in Context: A Comment on Sangiovanni 
vi CONTENTS

\section{Part III. Morality and Law}

6. Taking International Legality Seriously: A Methodology for Human Rights

Allen Buchanan \& Gopal Sreenivasan

6.1 Instrumentalism and Human Rights: A Response to Buchanan and Sreenivasan

Erasmus Mayr

7. The Turn to Justification: On the Structure and Domain of Human Rights Practice

Mattias Kumm

7.1 Human Rights and Justification: A Reply to Mattias Kumm Samantha Besson

8. Appreciating the Margin of Appreciation Andreas Follesdal

8.1 The Margin of Appreciation Revisited: A Response to Follesdal George Letsas

\section{Part IV. Ideals and their Limits}

9. Dwelling in Possibility: Ideals, Aspirations, and Human Rights

Kimberley Brownlee

9.1 In What Sense Should Respect for Human Rights Be Attainable? A Response to Brownlee Rowan Cruft

10. The Nature of Violations of the Human Right to Subsistence Elizabeth Ashford

10.1 Remarks on Elizabeth Ashford's "The Nature of Violations of the Human Right to Subsistence"

Daniel Weinstock

\section{Part V. The Challenges of Politics}

11. Reflections on Human Rights and Power

Pablo Gilabert

11.1 Reflections on Human Rights and Power: A Commentary

400 Elizabeth Frazer 
CONTENTS Vii

12. The Hazards of Rescue

409

C. A. J. Coady

12.1 The Politics of Humanitarian Morality: Reflections on

"The Hazards of Rescue"

429

Vasuki Nesiah

\section{Part VI. Individuals, Borders, and Groups}

13. Human Rights and Collective Self-Determination

Peter Jones

13.1 Linking Self-Determination and Human Rights: Comment on Peter Jones

Will Kymlicka

14. Human Rights, Membership, and Moral Responsibility in an Unjust World: The Case of Immigration Restrictions

Alex Levitov \& Stephen Macedo

14.1 The Slippery Slope of Statist Cosmopolitanism: A Response to Levitov and Macedo

Seyla Benhabib

Index 


\title{
Introduction
}

\author{
Adam Etinson
}

Moral or political? Can't human rights be both moral and political-and can't they be so in a variety of senses? It is plausible to think so. But one could be forgiven for assuming that philosophers have come to think otherwise. ${ }^{1}$

Over the past decade or so, philosophers have grown divided over the question of how to properly conceive of human rights. On the one hand, there are "orthodox" theorists (sometimes referred to as "naturalistic,"3 "humanist," "traditional,"5 "oldfashioned," ${ }^{\circ}$ or "philosophical"7). These theorists think of human rights as natural rights: moral rights that we have simply in virtue of being human. On the other hand, there are "political" " theorists (sometimes referred to as "practical," "institutionalist,"10 or "functional"11) who think of human rights as rights that play a distinctive role, or set of roles, in modern international politics: setting standards of political legitimacy, ${ }^{12}$ serving as norms of international concern, ${ }^{13}$ and/or imposing limits on the exercise of national sovereignty. ${ }^{14}$

Some may wonder why it is worth reading what philosophers have to say about these matters. After all, wouldn't it be better if we spent our time promoting human rights, or doing human rights "work," rather than engaging in intellectual debates about what such rights really are (if it even makes sense to ask such a question)?

This is a legitimate concern. But the Orthodox-Political debate, as I shall refer to it here, is not blind to it. In some ways, the debate shows that philosophers too are puzzled about their role when it comes to human rights. And this is at least partly due to the multifaceted nature of human rights themselves - their involvement in various domains of human life and thought.

In one guise, human rights present themselves to us as a bundle of supposedly natural or objective moral facts-facts that determine what we owe to each other as

\footnotetext{
1 A special thanks to James W. Nickel and Rowan Cruft for helpful comments on an earlier version of this introduction.

${ }^{2}$ Tasioulas 2010. $\quad{ }^{3}$ Beitz 2009; Liao \& Etinson 2012. $\quad{ }^{4}$ Gilabert 2011. $\quad{ }^{5}$ Raz 2010.

${ }^{6}$ Buchanan \& Sreenivasan in this volume. $\quad{ }_{7}^{7}$ Jones $1996 . \quad{ }_{8}^{8}$ Raz 2010; Valentini 2011 a.

9 Beitz 2009; Wenar 2005. $\quad{ }^{10}$ Sangiovanni 2007. $\quad{ }^{11}$ Griffin 2008, p. 27; Tasioulas 2012.

${ }_{12}$ Dworkin 2011, pp. 332-9; Williams 2005, pp. 62-4. $\quad{ }^{13}$ Beitz 2009, p. 109.

14 Rawls 1999, pp. 78-82; Raz 2010, p. 328.
} 
human beings. The human right to freedom from slavery, for instance, looks a lot like this. ${ }^{15}$ It prohibits the enslavement of anyone by anyone, and it does so (by all appearances) objectively: the normative force of the prohibition, or the "wrongness" of slavery, does not depend on its recognition by any group or person, let alone any popular moral code, institutional system, or positive body of law. Slavery was not any less of a human rights violation when (not all that long ago) most of the planet thought that it was morally and legally permissible to hold slaves.

Seen in this light, human rights look like a topic in moral philosophy, one that can be approached with the traditional tools of the armchair philosopher: principled reasoning, moral intuition, and (when necessary) empirical information to help apply abstract norms to specific circumstances. This vision fits nicely with the Orthodox conception of human rights, which emphasizes their status as moral rights. And philosophers, on this view, have a reasonably clear intellectual and practical role to play when it comes to human rights: like natural rights theorists of the past, philosophers can be expected to tell us what human rights there are, why (and how) they exist, and what they concretely require of us.

But human rights present themselves to us in other guises as well. In addition to seeming morally real, or part of what the British legal philosopher H. L. A Hart called "critical" morality, human rights are also standards that many people around the world happen to believe in, which makes them part of various "positive" or popular moralities too. ${ }^{16}$ Moreover, human rights are deeply embedded in contemporary politics and lawboth domestically, regionally, and internationally. ${ }^{17}$

The fact that human rights are today explicitly recognized norms of popular morality, political practice, and legal institutions throughout the world-the fact that it is now perfectly meaningful to speak of things like human rights "culture," human rights "practice," the human rights "movement," and human rights "law"-is of enormous practical and theoretical significance.

It is of practical significance because it is hard to imagine how the promise of human rights will ever be fulfilled without things like real-world belief in their importance, as well as recognition in politics and enforcement through law. These are the chief mechanisms through which human rights are realized, or not realized.

It is of theoretical significance for a number of reasons. First, contrary to Platonic stereotypes, philosophers, like other theorists, do take an interest in the world around them. The recent surge in scholarship on human rights-not just in philosophy but also in history, law, political science, and international relations-has a great deal to do with the recent success of human rights as a public idea. If it were not for the increased profile of human rights in political rhetoric, the popular imagination, the media, and law, contemporary scholars of human rights would probably have devoted their

15 Article 4, The Universal Declaration of Human Rights [UDHR] (1948); Article 8, The International Covenant on Civil and Political Rights [ICCPR] (1966/1976).

16 Hart 1994, p. 301.

${ }^{17}$ For a comprehensive overview, see: Alston \& Goodman 2012; Nickel 2007, ch. 1. 
energies elsewhere-certainly, a large edited volume like this is unlikely to have found its way into existence. And this is no doubt as it should be, which raises a second point.

Sometimes we want philosophy to help us interpret or make sense of our ideals and practices as they are. At other times we quite reasonably want philosophy (as well as literature and the arts, etc.) to operate in a normative mode-that is, to help us reimagine our ideals and practices as they ought to be. Once we home in on the public life of human rights as a key object of theoretical interest, however, we might wonder how best to normatively appraise it. We can always try to imagine human rights practice, human rights law, or the human rights movement as they might (ideally) be. But this should be more than a haphazard effort. What are the standards against which these phenomena should be judged?

One answer, perhaps the most obvious one, is that we should judge the public reality of human rights by how well it lines up with the moral reality thereof. After all, if there is a moral human right to freedom from slavery, then presumably popular morality, politics, and law should reflect this. And this seems to be true of countless other moral human rights as well.

But this suggestion overlooks the fact that the positivization of human rights has a logic of its own. Like other kinds of law, human rights law is something more than just a vehicle for the expression of moral standards. The law is a public instrument that, among other things, is designed to facilitate stable and predictable social relations. Unlike moral norms, which might be enforced in any number of ways, legal norms are typically enforced by means of coercive power. ${ }^{18}$ And given the public role of law, there may be good reason for it to avoid ruling on issues that are marked by strong dissensus. Morality, by contrast, does not seem to operate under this same constraint; it can be as controversial as it turns out (or as we take it) to be.

With this in mind, perhaps not all (moral) human rights are well suited for legal protection. For instance, as John Tasioulas, a key champion of the Orthodox conception of human rights, has argued, the human right to a fair say in important family decisions (e.g., about the division of spousal labour) is morally plausible but nonetheless ill-suited for legal recognition. ${ }^{19}$ Despite their far-reaching effects and enormous potential for unfairness, such decisions are extremely difficult to regulate and (in any case) strike us as importantly "private."

In other instances, there may be good reason to codify a legal human right that has no direct moral counterpart. For example, as Gopal Sreenivasan and Allen Buchanan suggest in this volume, a legal human right to health has various potential benefits beyond the promotion and/or protection of health itself: these may include improvements in

${ }^{18}$ It is true that international human rights law is not coercively enforced in the way that domestic law typically is. That said, the norms of international human rights law are designed to be incorporated into domestic law, where they (standardly) would be coercively enforced (see: Article 2, ICCPR; Article 2, ICESCR). Thus, in a very important sense, these legal norms are developed with the aim of coercive enforcement in mind.

19 Tasioulas 2012, p. 2. Sen (2004, pp. 326-8) makes a similar point. 
happiness, social solidarity, economic productivity, and the more general realization of a just and humane society, etc. Perhaps these aggregate benefits, if real, are enough to justify the enactment of a legal human right to health even if it turns out that there is no equivalent moral right, as some contend. ${ }^{20}$

At the very least, these considerations complicate the task of evaluating human rights law. They suggest that responsibly measuring its success (or ideal content) is more than just a matter of seeing how well it conforms to, expresses, or enforces human rights morality-that we cannot know what legal human rights there should be simply by knowing what moral human rights there are, and vice versa. And perhaps something like this is true of popular morality and politics as well. After all, not all good moral causes make for good political platforms, institutional projects, or social movements.

For instance, one prominent complaint about the human rights movement is that, for all its noble intentions, its focus on basic liberties and social services distracts us from more pressing "structural" injustices, including historically unprecedented levels of global and domestic economic inequality. ${ }^{21}$ Perhaps there really are ways in which the belief in (or practical pursuit of) human rights-via popular morality, social mobilization, and/or political institutionalization - can have adverse effects overall. And perhaps these adverse effects give us reason to rethink how (or even whether) morally justified human rights should be institutionalized and socially disseminated.

All of this leaves the role of the philosopher somewhat unclear when it comes to evaluating the public life of human rights. Even if we suppose (no doubt contentiously) ${ }^{22}$ that philosophers are capable of moral expertise-and, in particular, expert knowledge of the moral requirements of human rights-this would still not guarantee them insight into what human rights politics and law, or what the human rights movement, ought to be like. The independent life and logic of these real-world phenomena makes their evaluation a special task of its own, perhaps one that philosophers (or at least moral theorists) are in no privileged position to pursue.

This is the kind of observation that motivates the Political approach to human rights. According to one of its most prominent defenders, Joseph Raz, the Political approach acknowledges that contemporary human rights "practice" (largely a legal phenomenon, in his view $)^{23}$ cannot be evaluated on the basis of moral insight alone. Just as it would be strange to evaluate the content of the law without some understanding of the functions of law in general, Raz suggests that contemporary human rights practice ought to be evaluated under the light of a faithful understanding of what it is that the practice aims to $d o$.

Following John Rawls, the original proponent of this approach, ${ }^{24} \mathrm{Raz}$ argues that the main function of human rights practice is political: to make states answerable to the international community when it comes to their treatment of individual persons.

${ }^{20}$ Buchanan \& Sreenivasan in this volume. Also see: Buchanan 2013, p. 53.

${ }^{21}$ For a broad discussion, see: Gilabert in this volume, Sec. 2.2.4. Also see: Moyn 2015 \& 2018.

22 See e.g. McGrath 2008; Nussbaum 2002; Singer 1972.

${ }^{23} \mathrm{Raz}$ in this volume. Also see: Etinson in this volume, for a broader discussion. $\quad{ }^{24}$ Rawls 1999. 
With this function in view, Raz outlines the standards against which the practice should be judged. Genuine human rights-those which ought to be recognized by the practice if they are not already - consist in the set of individual moral rights that can be justifiably held against states in this way, i.e. as potential defeaters of state sovereignty. Evaluating contemporary human rights practice is ultimately a matter of figuring out which moral rights these are, and then seeing whether or how well they are represented in the practice itself. ${ }^{25}$

Understood in this way, Raz's theory appeals to relatively ordinary moral and political considerations. It requires us to think, on the one hand, about which individual moral rights (if any) should be a matter of state responsibility, and on the other, about when (if ever) the failure to meet such responsibilities should render a state liable to external interference or review. ${ }^{26}$ No doubt, these are complex calculations, but they draw on ordinary normative considerations (about the grounds of individual moral rights, and of state sovereignty, etc.) that apply in various contexts, not just contemporary human rights practice.

Some proponents of the Political approach think that this is a mistake. According to Charles Beitz, for example, taking the normative independence of contemporary human rights practice seriously requires evaluating it entirely on its own terms-that is, in light of concepts and considerations that are unique (or "sui generis") to the practice itself. ${ }^{27}$ For Beitz, even the concept of rights operative in the practice is unique and unbeholden to standard theoretical understandings thereof. ${ }^{28}$ This might make the practice look deficient from various well-established theoretical points of view, but, as Beitz argues, so much the worse for the establishment: "Why should we insist that international human rights conform to a received philosophical conception rather than interpret them, as they present themselves, as a distinct normative system constructed to play a certain special role in global political life?"29

The Orthodox-Political debate, then, is as much about the nature and limits of philosophy as it is about human rights. It is as much a debate about how to theorize human rights-and to what end-as it is about human rights themselves. In part, the debate reflects recent trends in moral and political philosophy: trends that have opened up questions about how normative or "utopian" philosophical theory should be, ${ }^{30}$ about the role of moral theory (and "truth") in politics, ${ }^{31}$ and about the relevance of political institutions to political theory. ${ }^{32}$ But most of all the debate reflects the innate complexity of its subject matter-the many lives of human rights, as it were.

The title of this volume, then, is not meant to assert any kind of fundamental opposition or contradiction. Rather, it is meant to highlight this innate complexity,

\footnotetext{
${ }^{25}$ Raz 2010, p. 327.

${ }^{26}$ Raz 2010, pp. 335-6.

27 Beitz 2009, p. 12, 197.

${ }^{28}$ Beitz 2009, p. 119.

29 Beitz 2009, p. 61.

30 See e.g. Estlund 2014; Rawls 1999, esp. pp. 11-23; Valentini 2012.

${ }_{31}$ See e.g. Rawls 2005; Raz 1998; Quong 2010.

32 See e.g. Cohen 2010; James 2005; Sangiovanni 2007; Valentini 2011b; Waldron 2013.
} 
the philosophical debate that has grown out of it, and the many questions it continues to raise.

This volume has two central aims. First, it aims to make new headway in the Orthodox-Political debate, moving it beyond its current state of progress. The bulk of that work can be found in Part II, which is where the most direct contributions to the debate have been gathered. The second aim of the volume is to provide a state-ofthe-art discussion of a number of important topics that are closely connected to the Orthodox-Political debate, but not normally a focal point thereof. That work can be found in Parts I, III, IV, V, and VI.

So far, the Orthodox-Political debate has focused on questions about the nature of human rights (What are human rights?), their grounds (What justifies their normative existence or authority?), their content (What human rights are there?), and about the aims and methods of a philosophical theory of human rights in general. But as a debate that is, at its core, instigated by the complex status of human rights as both critical standards of morality, on the one hand, and positive standards of law, politics, and popular morality, on the other, it in fact raises a much broader set of questions.

This volume explores a handful of key topics within that broader set. These include questions about: the relevance of the real-world history of human rights to their philosophical comprehension (Part I); how to properly understand the relationship between human rights morality and law (III); how to balance the aspirational or "utopian" character of human rights-their description of an ideal world-with the requirement that they be feasible in the here and now (IV); the role of human rights in a world shaped by politics and power $(\mathrm{V})$; and how to make sense of the ascription of human rights to both individuals, on the one hand, and political communities, on the other (VI).

In exploring these adjacent topics, the volume aims not just to deepen our understanding of some important questions about human rights, but also to exploit the opportunity this provides for interdisciplinary engagement. Several of the authorcommentator pairings in the volume place scholars from different disciplines (including history, philosophy, international law, political science, and legal theory) into direct dialogue with one another on a shared topic. Human rights have become an extraordinarily active area of research in a wide variety of disciplines, but the coordination and communication of research across disciplinary boundaries is rare and frequently prone to misunderstanding. Working across these boundaries, or at least trying (as several authors in this volume do) to figure out how research on human rights in any one discipline bears on research in others, is an important task in its own right. It is also crucial to determining just where philosophical theory fits into the impressive range of work currently being done on human rights, both intellectually and practically, which is a key preoccupation of the Orthodox-Political debate itself. 
The remainder of this introduction aims to give the reader some sense of the content of the volume, of how it builds on current scholarship, and highlights key starting points for critical reflection. ${ }^{33}$

\section{The Relevance of History}

The volume begins with a series of contributions that tackle the question of how the history of human rights bears (or should bear) on the philosophy thereof. What relevance, if any, do historical claims about human rights (e.g. about the series of events that lead to the UN General Assembly's adoption of the Universal Declaration of Human Rights on December 10th, 1948) have to the conceptual claims (e.g. about the nature of human rights) that philosophers tend to be interested in?

It is easy to picture philosophers (concerned, as one might imagine, strictly with timeless and universal truths) adopting a hard-line stance here: one that denies that philosophy, properly understood, ought to take any account of historical facts about human rights. But interestingly, philosophers have by and large gone a different route. Historical claims about human rights have in fact played a prominent role in the Orthodox-Political debate. For example, in Raz's view, one of the main problems with Orthodox theories of human rights is their anachronism. By understanding human rights to be (in essence) natural rights, Raz argues that such theories fail to capture the special functions that human rights have come to play in international legal and political practice today. In other words, if Orthodox theories ever did provide a valid benchmark against which to evaluate human rights practice, in Raz's view they no longer do; the practice has changed in ways that render such theories irrelevant or obsolete.

Raz tries to provide us with what he thinks are the right criteria for evaluating human rights practice in a given historical period: one that starts roughly at the end of the Second World War-or, at the very latest, after the collapse of the Soviet Union ${ }^{34}$ and continues into the present day. During this period, Raz suggests that for the first time in history it has become internationally conventional to treat the violation of certain individual rights (called "human rights") as grounds for intervention in a state's sovereign affairs.

As already mentioned, Raz takes this to be the "distinctive" function of human rights practice. ${ }^{35}$ And even though other proponents of the Political approach, such as Charles Beitz and John Rawls, offer subtly different accounts of this function, ${ }^{36}$ their historical focus is much the same. ${ }^{37}$ All three of these thinkers see themselves as capturing, in theoretical terms, an important historical shift in the international order that

\footnotetext{
${ }^{33}$ For a state-of-the-art and comprehensive overview of contemporary philosophical debates about human rights, see: Cruft, Liao, \& Renzo 2015.

${ }^{34}$ Raz 2015, p. $217 . \quad{ }_{35}$ Raz in this volume.

36 See: footnotes 12, 13, and 14 in this introduction. $\quad{ }_{37}$ See: Beitz 2009, p. 13; Rawls 1999, p. 79.
} 
began sometime after the end of the Second World War, and which saw human rights take on a new regulatory role in global politics and law.

Orthodox theorists do not necessarily deny the reality of this shift, nor are they disinterested in the history of human rights. On the contrary, Orthodox theorists, just like their Political counterparts, are keen to capture (in theory) the distinctive functions attributed to human rights (in legal and political practice) since the end of the Second World War. ${ }^{38}$ Where Orthodox and Political theorists differ is in their reading of which of these functions are worth incorporating into the concept of human rights and which are not.

Orthodox theorists accept that human rights have been ascribed new and important institutional roles over the last half-century or so. What they deny is that these changes are of conceptual significance, or that they should (in some fundamental way) govern our evaluation of the practice.

Rather than emphasize the theoretical significance of historical shifts, Orthodox theorists tend to emphasize the significance of certain continuities across the historical trajectory of human rights. For example, James Griffin, a key proponent of the Orthodox approach, argues that the modern (post-1948) idea of human rights is identical to its Enlightenment era predecessor:

The notion of human rights that emerged by the end of the Enlightenment-what can reasonably be called the Enlightenment notion-is the notion we have today. There has been no theoretical development of the idea itself since then. It is not, of course, that there have been no developments of any sort. The League of Nations developed, through treaties, basic mechanisms for the international protection of human rights. The United Nations, through the Universal Declaration and subsequent instruments, created a largely agreed list of human rights, which has had wide ramifications in political life. International law now embodies human rights and has developed complex institutions of adjudication. And so on. But despite the many changes, none has been to the idea itself. The idea is still that of a right we have simply in virtue of being human, with no further explanation of what "human" means here. ${ }^{39}$

Tasioulas, for his part, makes broadly similar claims about the continuity between the contemporary idea of human rights (which he identifies, at its core, with a "distinctive moral sensibility") and the natural rights tradition. ${ }^{40}$

So part of what underlies the Orthodox-Political debate, then, is not so much a historical disagreement as a disagreement about the theoretical significance of (some events in) the postwar history of human rights. As such, the debate raises profound (and not at all obvious) questions about how and why history matters, as it were, and in particular how and why it matters for a philosophical theory of human rights. The two main chapters and three commentaries in this first Part of the book set out to answer these very questions.

\footnotetext{
${ }^{38}$ Griffin 2008, p. 29; Tasioulas in this volume, Sec. I.

${ }^{39}$ Griffin 2008, p. $13 . \quad{ }^{40}$ Tasioulas 2012, p. 26.
} 
Orthodox and Political theorists take an interest in the history of human rights because they believe that evaluating public practice requires historical perspective. Theorists on both sides agree that a philosophical conception of "human rights" that bears no resemblance to the historically contingent notion that has taken root in global politics, law, and society would fail to exert any meaningful critical leverage on the latter. ${ }^{41}$

This failure can be understood in different ways. ${ }^{42}$ On the one hand, it may be a semantic failure: a wildly unfamiliar theory of human rights (one that, say, portrayed them as the rights of only a small subset of all living persons) is unlikely to come across as a theory of human rights at all; contemporary audiences will intuitively dismiss it as "changing the subject" - as confusing apples with oranges.

On the other hand, it may be a failure of focus: a theory interested in determining what rights should be recognized by, say, international human rights law (IHRL), ought to take account of the real-world (and historically contingent) consequences of recognizing rights in that environment. For instance, if we learn that the norms of IHRL are meant to be incorporated into domestic and regional law, ${ }^{43}$ this gives us a reason to think that IHRL should recognize rights (like the right to social security) that can typically be protected by domestic institutions. In general, a theory that aims to evaluate the public practice of human rights needs to keep these and other historically contingent features of the practice in focus; otherwise, its recommendations will be "so remote from the practice of human rights as to be irrelevant to it." ${ }^{44}$

In the first chapter of the volume, Martti Koskenniemi suggests that studying the history of human rights is crucial to more than just meaningful philosophical engagement with public practice-history is, in fact, a valuable replacement for abstract philosophical theory. In Koskenniemi's view, there is not much to be gained from using philosophical reasoning to approach questions about what human rights are, why they exist, what they require of us, and how best to enact them in public life. When we try to do this, he suggests, even a cursory survey of the philosophical literature will show that we run into intellectual dead ends and interminable debates. Against this (gloomy) background, Koskenniemi argues that we can look to history as a way out-a way of answering some of the questions philosophy puts before us but without becoming bogged down in impossible abstractions.

Koskenniemi uses three episodes in the history of human rights (spanning from the 16 th to the 18th centuries) to illustrate what he thinks we can learn, generally speaking, from historical analysis. What these episodes show, in his view, is that rights claims, even when advanced under the most rigorous philosophical auspices, are ultimately tools of politics and a product of historical forces. Rights claims come in on all sides of political conflicts-both as a way of challenging entrenched interests and advancing them — and so the illuminating thing to understand about rights, Koskenniemi asserts,

\footnotetext{
${ }^{41}$ Beitz 2009, p. 61; Griffin 2008, p. 29; Raz 2010, p. 324; Tasioulas in this volume, Sec. I.

${ }^{42}$ See: Etinson in this volume, Sec. V. $\quad{ }^{43}$ See: fn. $18 . \quad{ }^{44}$ Raz 2010, p. 323.
} 
is not how they should be used but rather how they are used, and how they help political actors achieve certain ends in concrete historical circumstances.

In her helpful commentary, Annabel Brett suggests that Koskenniemi's dismissal of philosophy is less absolute than he makes it out to be. Brett suggests that Koskenniemi is opposed to "legislative" philosophical theories of human rights (theories that tell us "what human rights are," once and for all) but would accept a more speculative type of philosophy that offers "an imaginative construction of how human rights might be thought of, if we want to make a better world for living in." If this is a call for epistemically modest and historically informed philosophical work, then it should be welcomed. But it is hard to see how a philosophical theory of human rights can be purged of any "legislative" aspect-that is, any judgment as to how such rights ideally ought to be practised and/or understood.

Nor is it clear that Koskenniemi has offered us good reasons for thinking that it should. Philosophy may be difficult, and its conclusions subject to seemingly interminable debate, but the same is true of other disciplines, including history. And Koskenniemi's insightful historical observations about the realpolitik functions of human rights discourse might plausibly be used as an aid to (rather than as a replacement for) normative inquiry into how current legal-political practice might be improved, and in particular how it might learn from past mistakes-a claim powerfully defended by Pablo Gilabert and C. A. J. Coady in Part V of this volume.

Like Koskenniemi, Samuel Moyn thinks that history provides us with valuable insight into the nature and functions of human rights. But unlike Koskenniemi, Moyn clearly believes that philosophy has an important role to play here too-at least so long as it avoids the dangers of excessive abstraction. Moyn's request is that philosophers approach human rights with the aim of being both faithful and helpful to public practice. He asks, of theorists, that they both accurately interpret the publicly shared understanding of human rights (in law, politics, and society, etc.), as well as offer suggestions about how it might be improved, particularly in ways that will enhance the realization of human rights-their transformation of the "world itself."

In order for philosophical theory to do this, Moyn argues, it needs to be highly alert to its historical moment. Philosophers need to think carefully about the historical forces that allowed human rights to break out as a popular (or "salient") idea in the past, the factors that have limited their realization or fulfilment thus far, and the circumstances (and conceptual modifications) that might well allow them to break out as a more popular and realizable ideal in the future.

In a sense, then, Moyn wholly agrees with the main participants in the OrthodoxPolitical debate: historical awareness is crucial for meaningful critical engagement with public practice. But he also highlights a special virtue of such awareness: its capacity to help theorists solve the very important practical problem of realizing human rights in a recalcitrant world.

Moyn is right to think that philosophy can make an important contribution to this task. Philosophical attempts to understand, critique, and reimagine human rights can help practitioners set basic goals as well as evaluate different strategies of 
implementation. But it is not obvious that philosophers should be so interested in developing theories of human rights that are palatable to the public at large, or that fit with (what we might call) the current historical "zeitgeist," in the way that Moyn suggests. Doing so may (possibly) make philosophical theories of human rights easier to realize, but it may also diminish their critical power or normative plausibility.

Furthermore, as John Tasioulas notes in his reply to Moyn, realizing human rights is a multi-disciplinary effort. It requires skill, effort, data, favourable circumstance, leadership, institutions, and human ingenuity that vastly outstrip anything philosophical insight alone can provide. With that in mind, Moyn's argument for a philosophy of human rights that (with the aid of history) is in charge of transforming both the world of ideas and the world itself may seem to trade on an overinflated understanding of the discipline.

That said, Moyn's argument serves as an important provocation for philosophers, one that forces them to address productive questions about the role of philosophy in the study and advancement of human rights, and about the role of history in philosophy. In his overview of this first Part of the volume, Jeffrey Flynn highlights some of the ways in which the disciplinary objectives of history and philosophy can both intersect and diverge in the context of human rights.

\section{The Orthodox-Political Debate}

Part II of the volume takes a direct look at the Orthodox-Political debate itself. The debate operates at four different levels, each of which addresses a different set of questions. These include questions about (i) the nature of human rights, (ii) their grounds, (iii) their content, and (iv) the aims and methods of a philosophical theory of human rights in general.

These questions are not entirely insulated from one another. If, for example, one adopts an Orthodox understanding of (i) the nature of human rights, understanding them to be moral rights that we have simply in virtue of being human, this exerts logical pressure on one's understanding of (ii) and (iii): presumably, the existence of such rights will depend on certain facts about human nature (a claim about grounds), and only those moral rights that are grounded in such facts will qualify as genuine human rights (a claim about content).

So there is a natural order of operations here; it makes good theoretical sense to start out by identifying (i) the nature of human rights, and to proceed onwards from there, allowing the dominoes to fall accordingly. But philosophical claims about the "nature" or "concept" of human rights can be opaque until we say something about their scope and purpose, as well as about the kind of evidence that can be marshalled in their favour - that is, until we say something about (iv).

For instance, when Orthodox theorists tell us that human rights are moral rights that we have simply in virtue of being human, it helps a great deal to know that this is not just a brute philosophical stipulation, but rather an attempt to home in on an understanding of human rights that embodies various virtues: (a) historical 
resonance, ${ }^{45}$ (b) fidelity to contemporary legal and political practice, ${ }^{46}$ (c) theoretical determinacy, ${ }^{47}$ (d) broad acceptability, ${ }^{48}$ and (e) ethical or normative plausibility. ${ }^{49}$ Similarly, when Political theorists say that human rights are individual moral rights that limit the exercise of national sovereignty, it helps just as much to know that this is an attempt to identify the role of "human rights" within the specific context of (b) contemporary international politics and law. ${ }^{50}$

In a sense, these details of scope and purpose form part of the meaning of claims about the nature of human rights; they help us understand what such theoretical claims ultimately amount to. Furthermore, these meta-theoretical details tell us something about how to evaluate claims about the nature or concept of human rightsthat is, about the kind of evidence that can be marshalled in their favour, or to their discredit. All of this is crucial to making rational engagement possible.

For this very reason, most theorists in fact start by identifying (iv) - the scope, purpose, and evidentiary grounds of their theory of human rights - and then move on from there. Beitz, Griffin, Raz, and Tasioulas all preface their theoretical claims with (meta-theoretical) declarations of aim and approach.

Indeed, Raz and Beitz think that what ultimately distinguishes a Political conception of human rights from its Orthodox counterpart is its stance on questions of just this type (iv). In their view, Political theories of human rights are distinguished not by what they say about the basic nature of such rights, but rather by their underlying commitment to saying something that, again, captures the functions attributed to "human rights" in contemporary international legal and political practice, whatever these ultimately turn out to be. ${ }^{51}$

This might seem puzzling given that, as already noted, Orthodox theorists like Griffin and Tasioulas also appear to share an interest in modelling these functions. And puzzling it is. The fact that Beitz and Raz take themselves to be offering not just a different philosophical theory, but a fundamentally different kind of philosophical theory from their Orthodox counterparts, highlights an important weakness of the debate so far. Despite their prefatory focus on questions of aim and approach, participants in the Orthodox-Political debate have rarely specified just how their answers to such questions compare to those of their interlocutors. This has left the debate vulnerable to basic misunderstanding and cross-talk. And several commentators have seized on this in recent years, arguing that Orthodox and Political theories of human rights are compatible in ways not recognized by their main proponents..$^{52}$

The contributions in this second Part of the volume directly address these two crucial levels of the Orthodox-Political debate. First, they address the core question of how best to conceive of (i) the nature of human rights. And second, they shed valuable

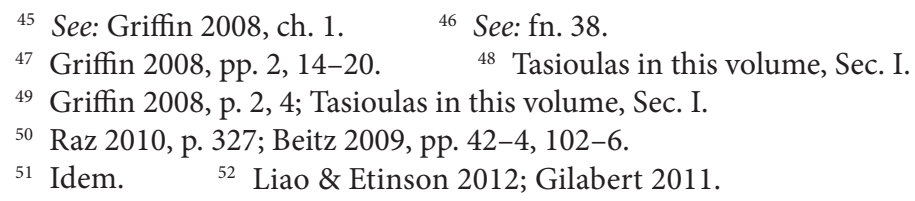


light on the meta-theoretical issue of (iv) what theorists are really doing (and what they should be doing) when they construct a philosophical theory of human rights that answers questions of this first sort, and others. Several contributions also address the claim that Orthodox and Political theories are at cross-purposes, or ultimately compatible with one another.

Jeremy Waldron's chapter wrestles directly with the first level of debate. There, the key issue, as he puts it, is to figure out what sense to make of the term "human" in human rights. Waldron presents us with two broad alternatives, which roughly correspond to the options presented by Orthodox and Political theories but also frame them in a new light.

One option is the "human bearer" approach (aka the Orthodox view), which understands human rights as rights born by all persons in virtue of their humanity. The other option is the "human concern" approach, which takes human rights to be the proper concern of all human agents-a concern that (as the Political view suggests) cannot be successfully rebuffed by appeals to national sovereignty.

These alternatives do not exhaust the contemporary theoretical landscape. For one, there is a common type of view that is plausibly categorized as "Political"-because it defines human rights as rights that serve the overtly political function of setting necessary standards of legitimate governance ${ }^{53}$-but that does not seem to fit within Waldron's binary schema. Nonetheless, the schema does effectively embrace the leading theoretical alternatives currently on offer, including those Waldron wants to criticize: Raz and Rawls's concern-based theories of human rights.

Waldron interestingly points out that debates about the nature of human rights cannot ultimately be resolved by appeal to the ordinary or everyday meaning of the term. He agrees with Raz that, analytically speaking, "the whole field is a bit of a mess." ${ }^{4}$ As Waldron sees it, "The question is not: What does the "human" in "human rights" really mean? The question is: what is the more convenient and illuminating use to make of the term in this context?"

If we take this point seriously, perhaps we should think of Orthodox and Political accounts of human rights as presenting us with something less than a full analytic definition thereof-that is, something less than the necessary and sufficient conditions under which any right qualifies as a human right. We might instead think of these accounts as describing "characteristic" or even contingent features of such rights in particular circumstances. ${ }^{55}$

Even on this score, however, Waldron thinks we should be wary of following Raz and Rawls in linking human rights to a specific kind of actionable concern on the part

${ }^{53}$ See: fn. 12.

54 "There is not enough discipline underpinning the use of the term 'human rights' to make it a useful analytical tool." (Raz 2010, pp. 336-7.)

55 See: Nickel's chapter in this volume for one possible way of making sense of this suggestion. 
of others, particularly in the international arena. Waldron's chapter meticulously highlights various costs or "inconveniences" of doing so: costs that include losing sight of the individualism of human rights-that is, the normal thought that these are rights that every human being, considered as a discrete individual person, can be said to have-and the implication of a (false) discontinuity between human rights and constitutional rights. Together, these concerns present a powerful challenge to the Political account of human rights, or at least to one version of it.

In his reply, Joseph Raz suggests that Waldron has misunderstood the basic point of developing a Political account. Raz denies having any interest in the question of what sense should be made of the "human" in human rights, or what the characteristic or core features of such rights might be. Instead, he insists that he is strictly interested in the legal and political practice of human rights, and in identifying the normative standards against which that practice should be judged-standards that, he thinks, are not (fully) captured by the moral human rights affirmed by Orthodox theorists.

But Raz's provocative response to Waldron may overstate things. After all, Raz is interested in identifying characteristic or core features of human rights; it is just that he confines his focus to those "human rights" explicitly recognized in contemporary international politics and law. And most importantly, it is not clear that Waldron's focus is any different, particularly given his more general interest in the analysis of legal (rather than purely moral) concepts. ${ }^{56}$

James W. Nickel's chapter takes a less partisan stance on the Orthodox-Political debate. Nickel's interest is wholly in questions of type (iv). That is, his chapter sheds light on the differences in aim and approach that underlie type (i) conceptual disagreements about the nature of human rights-differences of just the kind Raz brings up in his reply.

Nickel points out that Orthodox and Political accounts of human rights can plausibly be seen as having different aims or areas of "focus." For instance, Griffin's Orthodox theory identifies features or functions (mainly, the protection of normative agency) attributable to human rights, understood as a set of authoritative moral norms, in any time period. His focus is atemporal. ${ }^{57}$ It also identifies features that such rights would have across a range of contexts of application-or "spheres" of life, as Nickel calls them. These include not just international but also domestic and interpersonal affairs. ${ }^{58}$ Political theorists like Rawls, Raz, and Beitz, by contrast, are more constrained in their focus. Their theories aim to capture features (such as the limitation of national sovereignty) attributable to human rights as they operate in modern times (post-1948), and particularly in international politics and law.

Understood in this way, Nickel argues, Orthodox and Political theories might be seen as offering compatible and even mutually correct accounts of human rights. But unlike some other recent work on the compatibility of Orthodox and Political

56 See e.g. Waldron 2012, pp. 13-15, to pick one example.

${ }^{57}$ Griffin 2008, pp. 50-1.

${ }^{58}$ Ibid., p. 170. 
perspectives on human rights, ${ }^{59}$ Nickel is careful not to suggest that his observations necessarily resolve the debate. Instead, he simply exhorts theorists to be more transparent about issues of focus, and to be more sharply aware of how their choice of focus compares to that of others-an issue that is all too important if the integrity of current philosophical debates is to be maintained going forward.

Adam Etinson's response casts some doubt on the conciliatory power of Nickel's analysis. Nickel's chapter implicitly draws on an accommodating master-view of human rights on which various orientations of focus are possible. But this master-view might be rejected by Political theorists, such as Charles Beitz and John Rawls, who think of human rights as (essentially) norms that govern the behaviour of states under modern circumstances-that is, as norms that operate in the contemporary international domain exclusively. In this respect, Nickel's analysis may be more of a participant in the Orthodox-Political debate than it pretends to be.

This does not stop Nickel's analysis from providing significant insight. And Etinson's commentary deliberately uses it to shed light on the meaning, justification, and importance of a poorly understood feature of the Orthodox-Political debate: the (ubiquitous) notion that philosophical theories of human rights should be "faithful to the practice" thereof. Etinson identifies and critically examines two independent arguments for this notion-one based on semantic, and the other on focus-related considerations of just the kind explored by Nickel.

Andrea Sangiovanni's chapter ambitiously covers questions of type (i) and (iv). Its most striking contribution is the addition of an alternative to the Orthodox and Political accounts of human rights: what Sangiovanni calls the "Broad View." The Broad View of human rights is distinguished by its accommodating power (hence the label). Its core conceptual claim (i) is that human rights are "those moral rights that ought to be of universal moral, legal, and political concern." So Sangiovanni seems to offer us a version of what Waldron calls the "human concern" approach to human rights.

But the type of "concern" at issue here is far more open-ended than it is on Waldron's view. Since many types of moral rights should plausibly concern us all, some human rights, according to the Broad View, will be moral rights that we have simply in virtue of being human (Orthodox), and others will be moral rights that limit the exercise of national sovereignty (Political). Human rights include rights of both these types, and more. In this way, the Broad View subsumes its Orthodox and Political counterparts.

Sangiovanni offers an array of interesting reasons for adopting this exceedingly broad understanding of human rights. But one of its key motivations is the diversity and breadth of human rights practice itself. Like Orthodox and Political theorists, Sangiovanni believes that a theory of human rights ought to be adequately faithful to the practice thereof. Unlike those theorists, however, he believes that the practice is too broad and diverse to be captured by any concept of human rights as specific as those of Orthodox and Political views. ${ }^{60}$

\footnotetext{
${ }^{59}$ See fn. $52 . \quad{ }^{60}$ See Tadros 2015 (p. 445), for a similar point.
} 
Some practitioners have little interest in whether or not the rights they affirm are grounded in considerations of humanity. Others will have little interest in whether they override considerations of sovereignty. And there is nothing wrong with this; in Sangiovanni's view, there simply is no deep moral unity underlying the various activities and interests of human rights practitioners.

This is a provocative claim. It questions an assumption that seems to be widely shared in the Orthodox-Political debate: that there is a single (reasonably specific) concept of human rights governing the "practice." At the very least, Sangiovanni is right to flag this assumption as one worthy of serious examination.

But the Broad View faces challenges of its own. One is, ironically, a problem of fidelity. The theory is so deliberately vague and open-ended that it seems to stretch well beyond any normal sense of the boundaries of human rights talk itself. For instance, since the welfare of animals is plausibly of universal moral concern, Sangiovanni's theory will include non-human animals among the bearers of human rights-a highly counterintuitive result. Other worries about the extraordinary breadth of the view are highlighted by Rainer Forst in his incisive commentary.

\section{Morality and Law}

The major instruments of human rights law (whether domestic, regional, or international) are often thought of as vehicles for the implementation of pre-existent moral rights. There are various reasons why this is so.

First, it is undergirded by the apparent "suprapositivity" ${ }^{61}$ of human rights-their possession of a normative authority (i.e. a moral existence or validity) that transcends their embodiment in law. As mentioned in Section I of this Introduction, the human right not to be enslaved seems to have just this type of authority. We have a duty to respect it even if the law fails to acknowledge as much. And it is natural to say the same about many other human rights as well. This opens up the possibility that human rights can motivate or justify their own legal embodiment; their suprapositivity makes them capable, at least in principle, of calling for the creation of law, rather than just being creatures of it.

A second key observation is that human rights law portrays itself as a medium for the enactment of suprapositive rights. The two core instruments of international human rights law (the ICCPR and ICESCR), for instance, both present themselves as engaged in the "recognition"-rather than the creation or stipulation-of human rights: "the equal and inalienable rights of all members of the human family".62 And these rights are said to "derive from the inherent dignity of the human person." ${ }^{3}$ This claim seems to imply that international human rights law is grounded in a moral status

${ }^{61}$ Neuman 2003, p. 1868. See also: Cruft, Liao, \& Renzo 2015, p. 5; Griffin 2008, p. 54.

${ }^{62}$ ICCPR, Preamble; ICESCR, Preamble. $\quad{ }^{63}$ ICCPR, Preamble; ICESCR, Preamble. 
or value that exists beyond it (hence its "inherence"), and that gains expression and protection through it. ${ }^{64}$

In addition to all of this, thinking of human rights law as a vehicle for the implementation of human rights morality is a very natural way of understanding its function as a distinct area of law. Generally speaking, areas of law are developed in response to, and defined by their service of, certain identifiable needs. International Aviation Law, for instance, addresses the need for universal standards governing air travel, air traffic safety, and associated activities.

In the case of human rights law, broadly speaking, the relevant need seems to be that of articulating, enforcing, regulating, and monitoring compliance with human rights, understood as (among other things) a set of pressing moral rights that require universal recognition. This is not the only way of understanding the distinctive role of human rights law, nor are these the only reasons for doing so, but it is a natural view that many philosophers, lawyers, and legal theorists have found attractive. ${ }^{65}$

However natural this thought may be, the relationship between human rights morality and law has come under intense scrutiny in recent years. Two questions in particular have received special attention. First, there has been controversy over whether (a) all moral human rights require legal recognition. And second, there has been some discussion about whether (b) only moral human rights can justify the enactment of legal human rights-that is, about whether human rights law serves justifiable purposes beyond that of implementing human rights morality.

The first claim (a) has received considerable and longstanding support. ${ }^{66}$ According to many, moral human rights—and indeed, moral rights in general ${ }^{67}$-are something like "laws in waiting." ${ }^{68}$ They are the kind of moral norms that ought to be incorporated into law and coercively enforced, if they are not already.

As already mentioned in this introduction, however, not all moral human rights seem worthy of legal recognition. Consider, again, the right (among spouses) to an equal or fair say in important family decisions. ${ }^{69}$ This certainly seems like a human right-one that all human beings are entitled to-but it nonetheless appears unworthy of legal recognition. Not only would it be extremely difficult for courts of law to adjudicate a right of this sort, such adjudication would interfere with the privacy of family life in ways that seem more broadly damaging or inappropriate. Similar concerns come up in the case of other plausible human rights, such as the right of mature children to

${ }^{64}$ There is plenty of room for disagreement here. (See e.g. Waldron 2012 and Waldron 2015, who thinks of human dignity as a principally legal doctrine.) I am simply articulating what I take to be a natural reading of this claim.

${ }^{65}$ See e.g. Cranston 1983 pp. 16-17; Griffin 2010, p. 353; Lauterpacht 1950, p. 74; Neuman 2003, pp. 1868-9; Nickel 2007, p. 10; Wellman 2011, ch. 4.

${ }_{66}$ See e.g. Cranston 1983, p. 16; Hart 1955, pp. 177-8; Habermas 2010, p. 470; Martin 1989, p. 83.

${ }^{67}$ Hart $1955 . \quad 68$ The phrase is from Sen 2004, p. 326.

${ }^{69}$ The example is borrowed from Tasioulas 2012, p. 2. 
(parental) respect for their autonomy, ${ }^{70}$ or the right of all human beings to respect in general. ${ }^{71}$

There is a way in which these examples can be accommodated by (a). Much depends on how we interpret the normative strength of the claim. If (a) is read strongly, as asserting that there is always a conclusive case in favour of positivizing any moral human right, then the prospect of accommodation is closed, and we have to decide whether to reject the examples or to reject (a).

On the other hand, if the claim is read more weakly, as suggesting only that there is always a pro tanto or prima facie case in favour of positivizing any moral human right, then the possibility of accommodation remains open. Indeed, arguably, the examples cited above are simply ones in which pro tanto reasons in favour of legal positivization are defeated by weighty concerns about justiciability, appropriate forms of punishment, and/or the value of privacy, etc. Perhaps there always is a pro tanto case in favour of legally recognizing moral human rights—or any moral right, for that matter-just not always a conclusive one.

While this conciliatory strategy might work, at least in principle, it is not clear that it provides us with insight into the thinking of any actual proponent of (a). This is because authors that defend (a) have rarely specified its strength-that is, whether they endorse the weak or strong version thereof. Jürgen Habermas, for instance, says variously that human rights are "oriented" towards, "designed" for, and uniquely amenable to institutionalization and coercive enforcement. ${ }^{72}$ But none of this really clarifies the normative strength of their alleged legalistic orientation.

There is no absolute need for reconciliation here of course. One plausible reaction to the examples is simply to reject (a) in both its weak and strong forms. And, indeed, if the examples are convincing, this may well be the more plausible way to go. After all, it is not obvious that there is even a pro tanto case to be made in favour of legally implementing the right to an equal or fair say in important family decisions, and considerably less obvious that this right is somehow a "law in waiting," uniquely oriented towards or designed for coercive legal enforcement.

Instead, we might take the examples to illustrate the plausibility of adopting a less legalistic understanding of moral human rights, and of moral rights in general. On one such understanding, a moral right simply identifies what some duty-bearer(s) owe, or are morally required to provide, to some right-holder(s). The question of whether (and how) that duty should be enforced by third parties is left entirely open to additional argument and circumstances. On another such understanding, moral rights do necessarily call for some form of third-party (i.e. social or institutional) enforcement, but not necessarily legal enforcement in particular. Perhaps in many or most instances legal measures will be appropriate, but in others we may find that enforcement via less formal social customs and attitudes is more advantageous.

\footnotetext{
70 Griffin 2010, pp. 354-5.

${ }^{71}$ Buchanan \& Sreenivasan in this volume, Sec. 4.

${ }^{72}$ Habermas 2010, p. 470.
} 
This last understanding of moral rights has a strong following and dates at least as far back as John Stuart Mill. ${ }^{73}$ When applied to moral human rights in particular, it makes ample room for the diversity of ways in which human rights find recognition and protection in the real world: through monitoring and information-sharing, public criticism and condemnation (or so-called "jawboning"), ${ }^{74}$ popular mobilization, and other informal mechanisms. As Tasioulas mentions in this volume, the widely endorsed 2011 "Guiding Principles on Business and Human Rights," developed by Professor John Ruggie, are a good example of this. ${ }^{75}$ These principles assign ambitious responsibilities for respecting human rights to business corporations, but they do not establish legal obligations of any sort. Rather, they aim to be effective by setting clear behavioural expectations that can serve as a focal point for social and political action.

The Millian understanding of moral rights is still compatible with their having some special orientation towards law. For instance, we might think of moral human rights as generally deserving (as a statistical and contingent matter) of legal recognition, or we might single out some subset of moral human rights as deserving of legal recognition, even if we accept that not all human rights are. ${ }^{76}$

The contributions in this third Part of the volume do not challenge the idea that moral human rights may call for diverse (potentially non-legal) forms of recognition, protection, and implementation. Their focus is instead on the moral functions of legal human rights-those human rights that are recognized in law. They approach this topic in two main ways. First, they examine whether (b) these functions are restricted to that of expressing correspondent moral human rights, or whether they include more than this. And second, they offer an account of the specific values realized by various systematic features of human rights law. Both of these projects offer a macroscopic supplement to well-known work on the value (and disvalue) of particular legal human rights, including the right to health, ${ }^{77}$ the right to democracy ${ }^{78}$ and the right to periodic holidays with pay, ${ }^{79}$ among many others.

Allen Buchanan and Gopal Sreenivasan's discussion starts from the assumption that international human rights law (IHRL) is an instrument or tool, one that serves a variety of moral purposes. Against the grain of the suggestion made earlier in this Section of the Introduction, however, they argue that the implementation of pre-existent moral human rights is not an essential part of what IHRL does.

${ }^{73}$ Mill 1989, p. 14; Sen 2004, pp. 320-8; Tasioulas 2012, p. 2.

${ }^{74}$ Nickel 2006, pp. 271-4.

75 Tasioulas in this volume, Sec. III.

${ }^{76}$ One view on which any such affirmation is impossible is that of Samantha Besson, according to whom moral human rights only exist once they have been given legal recognition. On this view, in other words, moral human rights are "children" rather than "parents" of their legal counterparts. See: Besson 2011.

77 Brownlee 2015; Hassoun 2015; Wolff 2012.

78 Benhabib 2011; Christiano 2011; Cohen 2010; Gilabert 2012.

79 Cranston 1983, pp. 7, 12-13; Griffin 2008, p. 209; Risse 2009; Waldron 1993, pp. 12-13. 
In their view, IHRL consists in a set of legal entitlements that: (i) individuals hold primarily against their state; (ii) become binding on states through a process of ratification; and (iii) can limit the exercise of sovereignty even within a state's own borders. Given that there might plausibly be a wide range of moral reasons to enact any given legal entitlement of this sort-as discussed in the case of the right to health-Buchanan and Sreenivasan argue that there is no reason why these entitlements should be limited to ones that correspond to pre-existent moral human rights, or even to moral rights in general. Thus, they deny (b), or what they call "the mirroring view": the idea that the only justifiable moral reason for enacting an international legal human right is that it corresponds to a pre-existent moral human right of similar content and character. ${ }^{80}$

In denying (b), Buchanan and Sreenivasan take themselves to be overturning a kind of orthodoxy within the philosophy of human rights, one that cuts across the Orthodox-Political divide. And indeed, to the extent that rejecting (b) involves rejecting the intuitive idea that legal human rights are a vehicle for the expression and protection of pre-existent moral human rights, Buchanan and Sreenivasan do reject a commonly held view.

But there is in fact little reason to think that this commonly held view stands or falls on the truth of (b). IHRL can be a vehicle for the expression, recognition, and enforcement of pre-existent moral human rights-indeed, this can even be its characteristic purpose, or most of what it does-even if it is sometimes justifiable to enact a legal human right that has no obvious moral counterpart. We may even find, as Erasmus Mayr suggests in his comments, that justifiable international legal human rights always do express corresponding moral human rights, despite this not being a strict or straightforward necessity. There is no logical contradiction here. Nor is it clear that any actual author holds the restrictive "mirroring view" (b) ${ }^{81}$ But even if Buchanan and Sreenivasan overestimate the revisionary nature of their position, their discussion helpfully identifies some of the central complexities involved in morally evaluating the content and structure of IHRL.

Mattias Kumm's chapter takes on just this evaluative task. His interest is in diagnosing the "moral point" of three structural or pervasive features of human rights law, with a special focus on the European system in particular. These features include: (i) the broad scope of legal human rights-their guarantee of much more than just minimally decent forms of existence; (ii) the fact that some legal human rights are regarded as subject to justifiable infringement, provided certain proportionality requirements are met; and (iii) the extensive variation both in terms of the formulation and judicial interpretation of human rights across jurisdictions and strata of human rights law.

Kumm's central suggestion is that we should interpret these practices as mandated by a conception of justice centered on the idea of a universal "right to justification"-a

${ }^{80}$ Also see: Buchanan 2013, pp. 14-23.

${ }^{81}$ Griffin, who Buchanan and Sreenivasan suggest can "naturally" be read as holding this view, explicitly denies it in at least one instance: Griffin 2010, p. 351. So too does Raz in this volume. 
constructivist principle of Kantian inspiration that has recently been championed by Rainer Forst. ${ }^{82}$ According to this basic right or principle of justice, political and legal institutions ought to be constructed in accordance with norms that free and equal persons can reasonably be expected to accept. For Kumm, legal human rights are a crucial vehicle through which the content of such norms is decided and expressed. And this makes them not only a central part of politics and law but also a key object of reasonable disagreement themselves. It is this (moral) centrality and (epistemic) contestability, Kumm suggests, that explains both the origin and value of features (i), (ii), and (iii) above: the broad invocation of human rights; their curtailment in cases of conflicting objectives; and extensive disagreement about their content.

Kumm presents this account as the "best justification" of the practice we have, not just as one possible moral justification thereof. In order to successfully demonstrate this, however, Kumm not only has to address possible gaps between his constructivist principle and the practices he seeks to vindicate-gaps that Samantha Besson, in her commentary, insists are real; he also needs to address other possible ways of justifying (i), (ii), and (iii). And this includes offering some argument to those who are not already convinced that Kantian constructivism (or some version thereof) provides the best framework for thinking about justice in general.

Kumm's analysis is further complicated by a simultaneous interest in both moral justification (the value of $x$ ) and historical explanation (the origins of $x$ ). Though it may only do so implicitly, Kumm's chapter attempts to uncover a logic that both justifies and explains key features of contemporary human rights practice. These are two very different tasks, however, and Kumm rarely engages in the kind of historical evidencegathering (e.g. about the intentions of key drafters, politicians, judges, and practitioners, etc.) necessary to accomplish the latter. In fairness, Kumm admits that his account offers only the beginnings of a complete argument. And in the meantime, it outlines an impressively comprehensive framework for evaluating human rights law.

Andreas Follesdal's chapter, like Kumm's, has a strong European focus. But Follesdal's interest is in gauging the value of a more singular and specific legal phenomenon: the so-called "Margin of Appreciation" (MA) doctrine famously practised by the European Court of Human Rights (ECtHR). The MA requires the ECtHR to show a degree of deference, under certain conditions, to the judgement of a domestic authority when determining whether it is in compliance with its treaty obligations under the European Convention on Human Rights (ECHR). In so doing, the doctrine effectively allows for member states to interpret and implement the ECHR in different ways. And for this reason it has been an object of both strong praise and condemnation. ${ }^{83}$ Follesdal nimbly explores a broad array of arguments on either side, but his leading hypothesis is that the leeway it provides can be justified by a general principle of respect for democracy, and particularly for democratic decision-making at the domestic level.

\footnotetext{
${ }^{82}$ See: Forst 2012. $\quad{ }^{83}$ See e.g. Benvenisti 1999; Letsas 2006; Shany 2006; Wilkins 2002.
} 
This justification has its limits, however. As Follesdal explains, when there is no good evidence to suggest that a state's action, law, or policy is backed by genuinely democratic support, or if basic democratic rights are themselves at stake, the ECtHR should refuse to grant the state a MA on that issue. In such "undemocratic" situations, the principle of respect for democracy no longer speaks in favour of the MA, and may indeed prohibit it.

Follesdal's account has the advantage of being valuably specific about what it is that makes the MA an attractive doctrine; he avoids the natural temptation of simply grounding this on the broad value of national "sovereignty" - indeed, as George Letsas suggests in his extensive commentary, a case built on respect for sovereignty may fail outright. But Follesdal's account also faces some hurdles. It is not easy, after all, to measure the democratic character of a judicial decision, piece of legislation, let alone of an entire state. Judges, for one, are often appointed rather than elected, making their democratic credentials especially hard to assess. And even if we want regional courts like the ECtHR to be making these kinds of measurements, there is a serious risk that very few actual states will qualify as sufficiently democratic to be granted an MAthat is, unless the bar is set quite low. The risk here is that justifiable applications of the MA would be so rare as to render the doctrine almost practically irrelevant.

\section{Ideals and their Limits}

Human rights are ideals. They set standards of conduct (and also of belief, attitude, and emotion) ${ }^{84}$ to which various agents are expected to conform. But how demanding are human rights? How far must we travel, as it were, to fulfil them? Is this even possible? For a volume that is about the relationship between the normative reality of human rights, on the one hand, and their imbrication in the concrete worlds of law, politics, and popular morality, on the other, these are central questions.

Most theorists agree that human rights are subject to a "practicability" or "feasibility" test. And a key reason for this is the plausibility of the common assumption that "ought implies can"- that a person or institution cannot be obligated to do the impossible. ${ }^{85}$ For example, one can hardly be obligated to rescue a child that is drowning on the other side of the planet. The sheer physical impossibility of such an act makes it an implausible object of duty. But human rights are standardly understood to correlate with duties; without duties, there can be no rights. And so human rights are naturally subject to such concerns about feasibility. As Maurice Cranston, one of the earliest authors to write on this topic, explains: "If it is impossible for a thing to be done, it is absurd to claim it as a right." ${ }^{\prime 8}$

${ }^{84}$ Not only is the UDHR framed (at least partly) as an educational document to be used for teaching or promoting belief in human rights, it also aims to promote certain moral attitudes: Article 1, for instance, demands that all human beings "act towards one another in a spirit of brotherhood" (my emphasis). For a defence of the idea that love is a requirement of human rights, see Liao 2015.

${ }^{85}$ For a classic critique, see: Sinnott-Armstrong 1984. $\quad{ }^{86}$ Cranston 1973, p. 66. 
But even if we accept the idea that human rights must be feasible, we can still reasonably ask how feasible they must be. Cranston himself believes that a genuine human right must be achievable (a) for all persons (b) today. For example, since (in his view) the widely proclaimed human right to periodic holidays with pay satisfies neither of these conditions, it is not a genuine human right. ${ }^{87}$

But this is an implausibly strong test. Even the universally recognized human right to bodily security seems likely to fail it, given that part of what this right requires is adequate institutional protection against attack (via effective law enforcement, legislative action, a competent criminal justice system, etc.), and providing this for every last person on the planet is probably not possible today, though it may one day be so.

The alternative is to adopt some weaker version of the feasibility test. And there is good reason to think that it should be quite a bit more flexible than Cranston's. One reason to think so is that there are often concrete steps that can be taken to make presently infeasible rights feasible in the near or distant future. For example, even if we cannot currently grant the human right to periodic holidays with pay to all persons, there are still steps (through advocacy, institution building, campaigning, etc.) that we can take today to make this a more universally realizable right in the future. When such steps are possible, when a right has this partial degree of feasibility, it seems feasible enough to perform the basic functions of (and thus count as a legitimate instance of) a right: it can assign meaningful and actionable duties to agents, even if these duties have an essentially forward-looking character.

Indeed, several authors have taken these observations to be grounds for thinking that human rights generate two distinct categories of duties: (i) "direct" duties to respect or fulfil human rights, and (ii) "indirect" duties to make respecting or fulfilling them a more feasible task in the future. ${ }^{88}$

The contributions in this fourth Part of the volume tackle two outstanding questions in this area of debate. First, they examine the common line of thought defended just above - that is, the idea that human rights must be feasible in at least some sense. And second, they ask how human rights can have the sort of dualistic normative character described just a moment ago. How can human rights both require (i) full and immediate respect or satisfaction (as in the case of, say, the right not to be tortured) while also setting (ii) long-term goals towards which we are expected to work in an incremental fashion (as in the case of, say, the right to periodic holidays with pay)? Is there any fundamental incoherence here?

${ }^{87}$ Cranston 1973, p. 66. The right is recognized in the UDHR, Article 24, and the ICESCR, Article 7(d).

${ }_{88}$ See: Beitz 2009, p. 121; Gilabert 2009, pp. 676-8. The distinction maps on fairly well to the juridical distinction between "minimum core" and "progressive realization" rights. See: Committee on Economic, Social and Cultural Rights, "General Comment No. 3" (1990). 
Kimberley Brownlee's chapter takes on the first of these questions. Against the grain of a good deal of contemporary theory, ${ }^{89}$ Brownlee argues that human rights need not pass any feasibility test, weak or strong. This is because, as she argues, contrary to what most assume, human rights do not need to be feasible in order to meaningfully and legitimately guide action; there is, in other words, nothing particularly "absurd" about claiming a right to the impossible. Indeed, as she explains, there are in fact many ideals that are unattainable and yet fully capable of guiding action.

One example, in her view, is the ideal of being a good parent, which she takes to be a so-called "sustainability ideal" in that it requires sustained fulfilment. It is of course impossible to always be a good parent. Even the very best parent will suffer intermittent lapses. And yet, it seems obvious that the ideal of being a good parent, suitably fleshed out, can serve as a meaningful and worthy guide to action nonetheless. Brownlee's claim is that human rights are like this too. Like sustainability ideals, they require continuous respect or satisfaction-which, as she explains, is impossible. Even if a government can succeed for a time at fully securing its citizens' human rights to, say, political participation and due process, "there will inevitably be circumstances in which some people are either denied due process or illegitimately disenfranchised due to errors or prejudices." But these inevitable lapses, and the consequent unattainability of human rights ideals, do not undermine their action-guiding character. Thus, not only are human rights infeasible, their being so is little cause for concern.

Brownlee's argument moves from the observation that (a) flawless compliance with human rights is impossible to the assumption that (b) compliance with human rights is infeasible simpliciter. But this move may be too quick. As Rowan Cruft points out in his response to Brownlee, even if full or perfect compliance with human rights is impossible, this would not rule out their being feasible in other "lesser" ways. Indeed, if it were not at least possible to approximate human rights ideals-like those of sustainably securing citizens' rights to political participation and due process-then, as Cranston points out, it would hardly seem rational to pursue them.

So there is reason to think that even Brownlee's understanding of human rights requires that they be feasible in some respect, which undermines her attempt to transcend contemporary debates about the stringency of the feasibility test altogether. Even if this is correct, however, it still leaves intact her provocative suggestion that full respect for human rights is an ideal out of reach for human individuals and institutions.

The main goal of Elizabeth Ashford's chapter is to defend subsistence rights (to basic food, housing, healthcare, etc.) against those who would dismiss them as "secondary" or even counterfeit ("manifesto") human rights..$^{90}$ Attacks of this sort have been advanced on various grounds, but Ashford's interest is in those grounded in the (apparent) non-urgency of subsistence rights, particularly when compared with traditional liberty rights.

89 See: Gilabert 2009 for an excellent overview.

90 See e.g. Cranston 1973, ch. 8; Feinberg 1970, pp. 254-6; O’Neill 2005. 
As she points out, liberty rights (like the right not to be tortured) have an obvious air of urgency about them: they are rights of the utmost moral priority and must be immediately complied with. However, subsistence rights (like the right to adequate healthcare) appear to have a more aspirational character: they are rights towards which we are meant to work, in a progressive, step-by-step manner. The concern, then, is that subsistence rights generate goal-like duties of type (ii) rather than genuine rights-based duties of type (i) and that, because of this, including them in standard lists of human rights risks "diluting" the moral force thereof. With subsistence rights in the mix, human rights appear to lack consistent moral urgency, and may (all too conveniently) be glossed over as rights that can be "deferred" as long-term projects in the works.

Ashford addresses these concerns in two main ways. First, she argues that subsistence or welfare rights are not alone in having an aspirational component. As mentioned, protecting liberty rights (such as the right to bodily security) is just as much of a longterm, progressively realizable project as is securing the means of subsistence for all. The development of an effective criminal justice system is a complex, incremental, and resource-intensive task. So, even if the aspirational aspect of human rights is something to lament, subsistence or welfare rights are not solely responsible for it.

Second, Ashford argues that, like other human rights, subsistence rights combine both aspirational and peremptory components. As she explains, developing Shue's tripartite analysis of rights, ${ }^{91}$ (a) the institutionalized protection of individuals against life-threatening deprivation may be a long-term project, but (b) the duty not to deprive, and (c) certain instances of the duty to aid the deprived, are "primary" duties of the utmost moral urgency, on par (in Ashford's view) with the duty not to torture.

Thus, the best way to avoid casting all human rights under the glow of their aspirational component is to be more clear-eyed and discerning about the variety of duties they are capable of generating. Ashford makes a good case for this variety, and also for the urgency of coordinated action and institution-building that addresses global subsistence needs today. But she leaves untouched the complicated question of what individuals are concretely required to do (e.g. advocate, vote, mobilize, aid, donate, etc.), and how much is required of them, in light of these obligations-a crucial next step in her analysis. Among its other valuable contributions, Daniel Weinstock's commentary helpfully illustrates some of the practical uncertainties we are likely to face here.

\section{The Challenges of Politics}

Part IV addressed the question of whether, and to what extent, human rights are constrained by facts about what is feasible or possible for (would be) duty-bearers. If, as many believe, human rights are so constrained, then it is likely that political facts will be included in this set. ${ }^{92}$ It would be strange if human rights required the politically

\footnotetext{
${ }_{91}$ Shue 1996a. $\quad 92$ See: Gilabert 2009, pp. 664-7.
} 
impossible or even unworkable: for instance, government by perfect consensus in large-scale societies.

But political facts do more than just limit the scope of what human rights can sensibly require. Human rights, on any familiar understanding, require political recognition and institutional enactment. And, for better or worse, they are pursued by actors that must navigate a world shaped by the forces of politics, warts and all. As such, human rights face a number of political challenges: not only is (a) their content constrained by the limits of political or institutional possibility; even once their content is decided, (b) their realization depends, to a substantial degree, on their political fortunes; and, more broadly, (c) the formulation and pursuit of human rights inevitably have political consequences, and may be subject to dangerous political pitfalls, that merit serious consideration.

One of the more widely discussed political challenges facing human rights is (b): the fact that their satisfaction depends (at least in part) on the will and capacity of political agents, particularly nation-states. The challenge is a grave one, especially if it is true that, as many believe, even when states do have the ability to comply with human rights, the political will is rarely there.

One popular argument for this cynical conclusion is furnished by so-called "realist" presuppositions about the behaviour of states in the international domain. According to realist theories of international relations, states act entirely in accordance with their perceived self-interest. And since there is currently no global human rights enforcer capable of making compliance with (costly) human rights standards a reliably rational choice for self-interested state actors, realists conclude (what is already supported, in their view, by considerable independent evidence) that states lack the will to comply therewith. ${ }^{93}$ The overall implication is that, however morally appealing they may be, human rights will be politically neglected for the forseeable future.

In recent years, several prominent scholars of international law have challenged this realist picture. For instance, Beth Simmons has argued that state compliance with international human rights standards can be incentivized even in the absence of global enforcement mechanisms, such as foreign intervention, international sanctions, monitoring, and public condemnation, etc. As she explains, domestic mobilizationpublic protest, grassroots activism, litigation, lobbying, etc.-can act as a powerful enforcement mechanism of its own. ${ }^{94}$

In other work, Ryan Goodman and Derek Jinks have argued that the ("soft") power of acculturation-essentially a form of peer pressure that operates within the international community - has been and can be a crucial factor promoting compliance with international human rights law. ${ }^{95}$ If these scholars are right, then we can more or less accept the realist's Machiavellian assessment of the motivating sources of state

\footnotetext{
93 See: Beitz 1979, pp. 11-67, and Coady 2008, ch. 1, for excellent discussions. For a recent example of a realist perspective on human rights, see: Posner 2014.

${ }^{94}$ Simmons 2009.
} 
behaviour, as well as acknowledge the lack of (coercive or "hard") power backing compliance with human rights at the international level, without concluding that human rights standards are doomed to be shirked by state actors; the reality would be more complicated and hopeful than that.

Realism has been used to highlight other political challenges for human rights as well. Most prominently, realists have suggested that human rights standards are not only flouted but also manipulated by states in ways that further their self-interest. For instance, it is often said that human rights-or, rather, claims about the violation thereof-are (and have been) used by powerful states to justify aggressive international actions that, at bottom, are motivated by the prospect of material and/or political selfgain. ${ }^{96}$ Here the concern is not, as it was just above, that human rights are politically impotent. On the contrary, the concern is that human rights are, in a sense, all too effective in politics, or rather effective in the wrong way. If we think of the manipulation of human rights by state actors as a (potentially ever-present) risk, this looks like a political challenge of type (c): that is, a dangerous political pitfall that afflicts their international formulation and pursuit.

These are two key political challenges for human rights. There are of course many others-including Rawlsian concerns about the need for a stable international consensus on human rights. ${ }^{97}$ The contributions in this fifth Part of the volume catalogue, in illuminatingly fine-grained detail, the immense variety of political challenges in this area. But just as important as this, and against the (highly polemical) grain of scholarship on this topic, they also devote constructive attention to the question of what implications we should draw from these challenges: that is, the question of what these challenges ultimately mean for the theory and practice of human rights, and what, if anything, can and should be done about them.

Is the manipulation and disregard for human rights by political agents a defect of the rights themselves or (perhaps more plausibly) of human beings and political institutions? Does the regularity of such events imply, as Raymond Geuss has suggested, that human rights are merely a "kind of puffery or white magic"? ${ }^{98}$ Do states that have a (e.g. colonial) history of manipulating human rights standards to their own political advantage lose the moral standing to promote human rights internationally today?99 Are the political challenges facing human rights surmountable, manageable, or intractable? And if they are not intractable, how should they be met?

Pablo Gilabert's chapter develops a constructive analysis of the normative and theoretical implications of what he calls "power-related" worries about human rights. Having observed that human rights are both shirked and manipulated by powerful political

\footnotetext{
96 See e.g. Douzinas 2007; Mutua 2002, esp. ch. 1; Zolo 2010, esp. pp. 563-5.

${ }_{97}$ Rawls 1999, esp. pp. 121-3; Cohen 2004. $\quad{ }_{98}$ Geuss 2001, p. 144.

99 My thanks to Rowan Cruft for raising this question.
} 
agents with alarming regularity, Gilabert notes that we can respond to this fact in three general ways.

First, we can think of it, as Geuss does, as an indication that human rights do not exist (normatively speaking) - that is, that they do not qualify as norms that we genuinely ought to respect. Second, we can think of it as an indication that human rights "practice"-broadly, the modern project of explicitly recognizing and promoting human rights in international law and politics-should be abandoned. And third, we can think of it as an indication that human rights practice ought to be (re)shaped in ways that address concerns about its political neglect, subversion, and abuse.

Gilabert favours the third response. The first, he thinks, is indefensible. Not only does it (very implausibly) assume that states can rid themselves of the moral obligation to respect human rights by regularly shirking it, it also fits poorly with the general tone of scholarship on this topic. In nearly all cases, authors that document the abuse, neglect, and manipulation of human rights by the powerful treat this as a lamentable fact. And presumably this is because, at bottom, they believe that human rights (or something very much like them) exist-that is, that states really ought to do the sort of things that human rights typically require of them, such as grant fair trials, refrain from torture, tolerate dissent, and offer basic services, etc.

Gilabert also finds the second response uncalled for. As he suggests, there is, as of yet, simply not enough evidence available to know whether human rights practice merits abandonment: whether overall it has done more harm than good, or whether (even if it has) it will clearly continue to do so.

In order to develop and give substance to the third response, Gilabert looks at a variety of power-related concerns about human rights, and tries to see how the practice might be reshaped in ways that address them. The chapter identifies a number of helpful desiderata of this sort. But perhaps its key observation is that power should not simply be seen, as it often is, as an obstacle to be constrained and eventually overcome, but also as something that the practice ought to harness and distribute in ways that help fulfil the promise of human rights.

Gilabert thinks empowerment should be "built into" the human rights project. Not only should individuals and groups be empowered (i.e. provided with the means) to acquire the objects of their human rights; they should also be able to play an active role in their elaboration and identification. Thus, political rights to equal representation and participation - to have one's voice "heard" in the public domain—should be seen as a central part of the human rights project, in Gilabert's view.

In her comments, Elizabeth Frazer argues that political rights will have to be supplemented by political knowledge-particularly knowledge of complex "power structures" that perpetuate various forms of domination in society-if Gilabert's democratic vision is ever to be achieved. That seems right, but Gilabert's proposal requires other forms of supplementation as well. While individual democratic rights (and political knowledge) are a sensible way of addressing concerns about various imbalances of power within the domestic context of the nation-state, it is not obvious how they are 
meant to work at the international level, where the prospect of genuinely democratic institutions is hugely remote, and which is the focus of so many of the worries Gilabert sets out to address in the first place.

C. A. J. Coady's chapter explores some of the political and moral risks ("hazards") involved in efforts to implement human rights through acts of rescue, whether in the form of aid or military intervention. Coady identifies a number of such risks, which he labels "moralisms." Moralisms are, in essence, moral beliefs and practices that fail to take account of relevant prudential considerations. In the context of rescue, Coady argues, with the help of powerful historical examples, that we ought to be particularly careful to avoid pitfalls like the moralism of "deluded power" (which involves the false belief that moral conviction on its own has the power to do substantial good in the world), of "unbalanced focus" (which involves an undue fixation on some moral considerations at the expense of others), of "abstraction" (which involves insufficient attention to the concrete circumstances in which one aims to act), and of "imposition" (whereby an outsider's vision of the needs and/or desires of a community is unduly imposed upon it).

Coady is moderate and sensible in his treatment of these concerns. The solution, in his view, is not to abandon rescue efforts altogether ${ }^{100}$-although in her comments Vasuki Nesiah suggests that Coady should be more profoundly concerned about the growing prominence of "rescue" as a human rights imperative. Instead, like Gilabert, Coady recommends that we use these critical observations constructively, to formulate lessons that can help improve decision-making and rescue efforts in the future.

If we accept, as Coady does, that rescue is sometimes necessary even though it may well lead to disaster, whether as a result of moralism or any other failure, then his constructive approach is indispensable. Clearly, we ought to think about how to do necessary work well. The looming challenge is to figure out how best to institutionalize and develop the enlightened sense of prudence or caution that Coady argues for, but (and this is no small feat) without letting it transform, when practised, into a paralytic aversion to rescue that he sees no reason to embrace.

\section{Individuals, Borders, and Groups}

Most agree that human rights are typically held by individual human beings, principally against the state. That is, after all, true of most of the rights one finds in key international human rights documents like the UDHR, ICCPR, and ICESCR. ${ }^{101}$ And critics have taken note. The ostensible individualistic orientation of human rights brought them firmly into the crosshairs of the so-called "communitarian" critique of rights that flourished during the 1990s. Drawing partly on Marx, ${ }^{102}$ communitarians

100 See e.g. Zolo 2010.

101 See: Nickel 2007, ch. 1; Nickel 2014, sec. 1, for a longer list of prominent features of such rights.

102 See: Gilabert in this volume, for a brief discussion. 
insisted that the affirmation of individual rights distracts us from the importance of "community," social responsibility, socio-economic equality, and the basic interdependence of human beings. ${ }^{103}$

These criticisms have been vigorously contested. ${ }^{104}$ And the communitarian critique is at least partly undermined by the fact that affirming rights simply is a way of affirming certain social responsibilities. Rights, or rather "claim rights," of which human rights are mostly composed, logically correlate with duties-duties owed to the rightsbearer by some agent or set thereof. ${ }^{105}$ And so issues of social responsibility and human interdependence are, in a very basic sense, never far from view when rights claims are at stake, regardless of whether these are individual claims or not.

Another fact that undermines the communitarian critique is that human rights instruments are designed to protect and promote community life in various ways. The UDHR recognizes rights to nondiscrimination (Article 1), equality before the law (Article 7), freedom of association (Article 17), and freedom of thought and expression (Article 18), all of which are crucial to the flourishing of minority groups. ${ }^{106}$ The ICCPR-leaning on the Convention on the Prevention and Punishment of the Crime of Genocide (1948) - recognizes "genocide" (the targeting of a specific group for destruction) as a grave and punishable crime under international law (Article 6). And the ICCPR explicitly recognizes the rights of "ethnic, religious or linguistic minorities ... to enjoy their own culture, to profess and practice their own religion, or to use their own language" (Article 27).

Perhaps most notable of all, both the ICCPR and ICESCR recognize (in Article 1, no less) the rights of "peoples" to political self-determination: "to freely determine their political status and freely pursue their economic, social, and cultural development." One of the remarkable features of this right, as well as some of those listed above, is that it is clearly assigned to groups rather than individual persons. The right grants an entitlement of self-rule to a "people" - a political collective- not to any one person as such. This represents a strong break from the general focus on individual rights in international human rights law, and provides it with a striking communitarian component.

But the inclusion of group rights within standard lists of human rights also opens up difficult questions of its own. For one, (i) it raises questions about who, or rather what, can hold human rights. The ICCPR and ICESCR might assign human rights to groups, but how does this fit with other features often attributed to such rights: for instance, that they are held (a) universally by all persons, including by those who (for any number of reasons) lack membership in a political group; or that they are held (b) naturally, simply in virtue of one's humanity, and therefore not as a result of contingent facts about group affiliation? Upon reflection, the inclusion of group rights in

103 See e.g. Glendon 1991, ch. 4; Etzioni 1993, pp. 1-23; Yew 1992.

104 See e.g. Alston \& Goodman 2012, pp. 509-30; Donnelly 2013, chs. 7, 12; Gould 2004, ch. 5; Shue 1996b, pp. 218-19; Taylor 1999.

105 See: Hohfeld 1923, pp. 36-8; Feinberg 1970.

106 See: Nickel 2007, ch. 10 and Donnelly 2013, ch. 3, for good discussions on this. 
standard lists of human rights may seem like a category mistake, and in some cases also a moral mistake. ${ }^{107}$

Second, (ii) the recognition of group rights generates special normative tensions within human rights doctrine. The right of peoples to self-determination is naturally understood to include a right to border control-to set rules that determine the conditions of entry, visitation, passage, immigration, and exit. It's hard to imagine how a group could be genuinely self-determining without the ability to exercise some degree of control over such matters. But this right (to exclude) comes into conflict with other human rights that guarantee freedom of movement across borders: for instance, the right to leave any country, ${ }^{108}$ as well as the right to seek and enjoy asylum from persecution. ${ }^{109}$

In a sense, then, the demands of international human rights sit on either side of political borders; they are a source of duties to let outsiders in and of permissions to keep them out. It is not unusual for human rights to generate conflicting practical demands-as they famously do, for instance, in the case of the human rights to security ${ }^{110}$ and to privacy. ${ }^{111}$ But any such tension calls for an effort to "balance" competing claims, which requires careful evaluation of the considerations at hand.

These questions about how (and indeed whether) human rights serve the interests of political groups engage a core focus of this volume: the political dimensions of human rights. To date, (i) the status of group rights within the human rights corpus remains a controversial question, ${ }^{112}$ and (ii) the normative or practical tensions generated by the affirmation of such rights have been a source of energetic and unresolved debate. ${ }^{113}$ The contributions in this sixth and final Part of the volume aim to make progress on both of these key issues.

Peter Jones's chapter examines whether the right of peoples to self-determination can properly be thought of as a human right: question (i). Jones is interested in whether a case can be made for the moral existence of such a human right, but assumes that a favourable answer to this question would justify its legal recognition as well —an assumption that, as noted in Section III of this introduction, can reasonably be disputed.

Jones argues that group rights like the right to self-determination can indeed be understood as human rights, but only under certain conditions. One such condition, in his view, is that the right be "collective" in a special sense: not in virtue of being borne by a single corporate entity, but rather as a result of being a right that individuals

\footnotetext{
107 Consider, for instance, the ECtHR's 2011 decision that a corporation, the Yukos Oil Company, holds human rights [in Yukos Universal Limited (Isle of Man) $v$ The Russian Federation]. My thanks to Rowan Cruft for bringing this example to my attention.

108 UDHR, Article 13; ICCPR, Article 12. $\quad 109$ UDHR, Article 14.

${ }_{110}$ UDHR, Article 3; ICCPR, Article 6, $9 . \quad{ }_{111}$ UDHR, Article 12; ICCPR, Article 17.

112 See e.g. Buchanan 2013, p. 77; Donnelly 2013, ch. 3; Griffin 2008, ch. 15; Newman 2011; Nickel 2007, ch. 10

113 See e.g. Abizadeh 2008; Benhabib 2004; Carens 2013; Miller 2005; Risse 2008.
} 
hold jointly, and only jointly. This condition is important, Jones argues, because it means that the human right of peoples to political self-determination is ultimately born by individual human beings, which he thinks is an essential feature of human rights in general.

Another condition is that the right concern itself only with what Jones calls the "determination principle." This principle requires that there be a one-to-one match between the people whose collective lives are determined in a certain territory and those who do the determining. In effect, it grants a right to self-determination to all extant political groups, regardless of their composition, history, and current geographical extension. However, the principle takes no position on what Jones calls the "issue of selfhood"-that is, the question of which specific units of population qualify as "peoples" deserving of political constitution in the first place. Jones argues that the determination principle can be brought within the compass of human rights thinking, but that the issue of selfhood cannot.

The reason for this, he explains, is that we are unlikely to discover any general rules that allow us to determine which groups deserve to be politically constituted as a "people" and which do not. The territory of the world is not fairly or justly divided. Many populations have been wrongly stripped of territories and political control that they deserve-that much is clear. Nonetheless, it is often difficult to know exactly where just borders should lie, or exactly which populations (and sub-populations) deserve to keep or newly gain political independence as a result of their special history, identity, or status as a "people." If any answers are to be found here, they are likely to be highly contextual, historically contingent, and will often be morally hazy. This makes the issue of selfhood an unsuitable topic for human rights doctrine, in Jones's viewwhich he thinks of as oriented towards more universalistic and less morally ambiguous concerns-though he admits that the issue can and should be approached with other normative tools.

As Will Kymlicka points out in his commentary, this is a severe restriction. If the purpose of the human right to collective self-determination is to protect peoples against unjust interferences with their sovereignty, then the issue of selfhood cannot really be avoided. After all, as Kymlicka points out, some of the most insidious violations of sovereignty-such as annexation and forced settlement-target the composition of the demos; they strip political power from a people without quite violating the determination principle itself, since in theory they may allow the (altered) demos to self-govern. Surely, Kymlicka argues, the human right to collective self-determination should protect peoples against such forms of international aggression, and so take the issue of selfhood on board.

Kymlicka's criticism is grounded in his provocative claim that the chief purpose of international human rights norms is to remedy or address fundamental injustices created by the international legal-political order itself, and that a significant portion of these injustices include violations of selfhood of the kind described just above. But we can question Jones's position on its own grounds. 
Jones argues that violations of selfhood should not be covered by the human right to collective self-determination because this would force human rights practitioners to tackle highly contextual and morally ambiguous problems. But this seems like an odd reason to limit the right. Many core human rights, such as the right to an adequate standard of living, ${ }^{114}$ merely point the way towards what will inevitably be a highly contextual determination of what individual human beings need to adequately flourish in specific circumstances. And international human rights documents contain limitation clauses precisely because the pursuit of such rights is readily understood to mire agents in morally ambiguous predicaments that require costly sacrifices and sometimes even the infringement of human rights themselves. ${ }^{115}$ If the realization of human rights is already a highly contextual and morally hazardous affair, then there is little reason to think that the human right to collective self-determination should be spared from this.

Alex Levitov and Stephen Macedo's chapter delves into some of the concrete normative ambiguities we are likely to encounter as a result of recognizing the human right to collective self-determination. Levitov and Macedo are specifically interested in the apparent conflict between this right, which seems to grant peoples a permission to exclude outsiders, and other human rights (or normative considerations) that guarantee universal freedom of movement across borders: question (ii).

Levitov and Macedo believe that this normative conflict is real. But they develop a framework (which they call "cosmopolitan statism") within which it is meant to be managed, if not entirely resolved. The distinguishing feature of their position is that it invests the state, and our obligations to compatriots, with paramount normative significance (hence its "statism"), while also acknowledging ambitious duties towards outsiders (hence its "cosmopolitanism"). This latter set of duties include (a) natural duties of rescue, (b) natural duties to assist outsiders in domestic institution-building, and (c) duties of reciprocity, which include duties to engage outsiders fairly, to address past wrongs, and to improve international institutions so that reciprocally fair interstate relations are easier to establish.

Because Levitov and Macedo acknowledge such strong obligations both to compatriots and to outsiders, the conflict that they aim to arbitrate turns out to be a "hard case." So much so that they are keen to stress the "reasonableness" of multiple approaches to it - that is, multiple immigration schemes that balance these duties in different ways, from more closed to more open.

Given this reasonable plurality, they argue, states deserve a wide degree of discretion, or freedom from external interference, in deciding just what type of immigration scheme to adopt. Indeed, following language familiar from Rawls, ${ }^{116}$ Levitov and Macedo suggest that states should even be free to adopt unreasonably or unfairly restrictive immigration policies, providing these don't fall into the domain of the "fully

\footnotetext{
114 UDHR, Article 25; ICESCR, Article 11.

115 UDHR, Article 29; ICESCR, Article 4; ICCPR, Article 18.
}

116 Rawls 1999, pp. 74-5. 
unreasonable." Fully unreasonable immigration policies, Levitov and Macedo explain, violate the human rights of outsiders, which is intolerable.

Thus, for instance, a state may refuse to grant entry to low-skilled migrant workers whose basic needs are already met at home, but it cannot refuse entry to individuals fleeing persecution, which would amount to a clear violation of their human rights. And to make sure that states stay well within the boundaries of the reasonable when it comes to immigration, Levitov and Macedo suggest that immigration policies should be regularly vetted by multilateral international organizations specifically charged with this task, and capable of imposing reputational and material penalties when states fall short.

In her wide-ranging commentary, Seyla Benhabib points out that immigration policies determine more than just how many outsiders will be allowed into a state, and under what conditions; they also determine how outsiders are treated once they gain entry, whether legally or illegally. Benhabib turns our attention from non-citizens outside our borders to those who are already here among us, and she persuasively argues that states should have no discretion when it comes to respecting the human rights of domestic non-citizens, including their socio-economic human rights: "by penalizing unsanitary and exploitative work conditions, and by expediting the integration of undocumented migrants into the social network of the country in question through state or city-issued identity cards, the issuance of social security numbers, etc."

Interestingly, Benhabib also points out that states that fully respect the human rights of domestic non-citizens may paradoxically see a reduction in immigration, since this is likely to reduce the availability of cheap, exploitative labour. These observations provide an important complement to Levitov and Macedo's analysis of border policy.

There is an ambiguity that courses through Levitov and Macedo's discussion of the human right to collective self-determination. On one understanding of the right, it grants peoples a permission to exclude non-citizens (whether at home or abroad) from entry or full membership. But Levitov and Macedo adopt a more ambitious interpretation of the right, as one that grants peoples a permission to unfairly exclude outsiders from entry or full-membership-essentially, a permission to do wrong.

This is not an implausible interpretation of the right. But it is far from inevitable. And moreover, Levitov and Macedo's focus on the extent of peoples' freedom to be unfair or unreasonable distracts their analysis from the question of just what a fair and reasonable immigration policy should look like in the first place. Readers looking for an answer to the latter question rather than the former will want to hear more.

\section{References}

Abizadeh, Arash (2008) "Democratic Theory and Border Coercion," Political Theory, Vol. 36, No. 1, pp. 37-65.

Alston, Philip \& Goodman, Ryan (2012) International Human Rights (Oxford: Oxford University Press). 
Beitz, Charles R. (1979) Political Theory and International Relations (Princeton: Princeton University Press).

Beitz, Charles R. (2009) The Idea of Human Rights (Oxford: Oxford University Press).

Benhabib, Seyla (2004) The Rights of Others: Aliens, Residents and Citizens (Cambridge: Cambridge University Press).

Benhabib, Seyla (2011) "Is There a Human Right to Democracy? Beyond Interventionism and Indifference" in Claudio Corradetti (ed.), Philosophical Dimensions of Human Rights: Some Contemporary Views (Cambridge: Cambridge University Press), pp. 191-213.

Benvenisti, Eyal (1999) "Margin of Appreciation, Consensus, and Universal Standards," New York University Journal of International Law and Politics, Vol. 31, No. 1, pp. 843-54.

Besson, Samantha (2011) “Human Rights: Ethical, Political... or Legal?" in D. Childress (ed.), The Role of Ethics in International Law (Cambridge: Cambridge University Press), pp. 211-45.

Brownlee, Kimberley (2015) “Do We Have a Right to the Political Determinants of Health?" in Rowan Cruft, S. Matthew Liao, \& Massimo Renzo (eds), Philosophical Foundations of Human Rights (Oxford: Oxford University Press), pp. 502-15.

Buchanan, Allen (2013) The Heart of Human Rights (Oxford: Oxford University Press).

Carens, Joseph (2013) The Ethics of Immigration (Oxford: Oxford University Press).

Christiano, Tom (2011) "An Instrumental Argument for the Human Right to Democracy," Philosophy and Public Affairs, Vol. 39, No. 2, pp. 142-76.

Coady, C. A. J. (2008) Messy Morality: The Challenges of Politics (Oxford: Oxford University Press).

Cohen, Joshua (2004) "Minimalism About Human Rights: The Most We Can Hope For?" The Journal of Political Philosophy, Vol. 12, No. 2, pp. 190-213.

Cohen, Joshua (2010) "Is There a Human Right to Democracy?" in The Arc of the Moral Universe and Other Essays (Cambridge, Mass.: Harvard University Press), pp. 349-73.

Cranston, Maurice (1973) What are Human Rights? (London: The Bodley Head).

Cranston, Maurice (1983) “Are There Any Human Rights?" Daedalus, Vol. 112, No. 4, pp. 1-17.

Cruft, Rowan, Liao, Matthew, \& Renzo, Massimo (2015) "Introduction" in Rowan Cruft, S. Matthew Liao, \& Massimo Renzo (eds), Philosophical Foundations of Human Rights (Oxford: Oxford University Press), pp. 1-45.

Donnelly, Jack (2013) Universal Human Rights in Theory and Practice (Ithaca, NY: Cornell University Press), Third Edition.

Douzinas, Costas (2007) Human Rights and Empire: The Political Philosophy of Cosmpolitanism (Milton Park: Routledge-Cavendish).

Dworkin, Ronald (2011) Justice for Hedgehogs (Cambridge, Mass.: Harvard University Press).

Estlund, David (2014) “Utopophobia," Philosophy and Public Affairs, Vol. 42, No. 2, pp. 114-34.

Etzioni, Amitai (1993) The Spirit of Community (New York: Crown Publishers).

Feinberg, Joel (1970) “The Nature and Value of Rights," Journal of Value Inquiry, Vol. 4, No. 4, pp. 243-60.

Forst, Rainer (2012) The Right to Justification: Elements of a Constructivist Theory of Justice, tr. Jeffrey Flynn (New York: Columbia University Press).

Geuss, Raymond (2001) History and Illusion in Politics (Cambridge: Cambridge University Press).

Gilabert, Pablo (2009) "The Feasibility of Basic Socioeconomic Rights: A Conceptual Exploration," Philosophical Quarterly, Vol. 59, No. 273, pp. 659-81. 
Gilabert, Pablo (2011) "Humanist and Political Perspectives on Human Rights," Political Theory, Vol. 39, No. 4, pp. 439-67.

Gilabert, Pablo (2012) "Is There a Human Right to Democracy? A Response to Joshua Cohen," Latin American Journal of Political Philosophy, Vol. 1, No. 2, pp. 1-37.

Glendon, Mary Ann (1991) Rights Talk: The Impoverishment of Political Discourse (New York).

Goodman, Ryan \& Jinks, Derek (2013) Socializing States: Promoting Human Rights Through International Law (Oxford: Oxford University Press).

Gould, Carol C. (2004) Globalizing Democracy and Human Rights (Cambridge: Cambridge University Press).

Griffin, James (2008) On Human Rights (Oxford: Oxford University Press).

Griffin, James (2010) "Human Rights and the Autonomy of International Law" in Samantha Besson \& John Tasioulas (eds), The Philosophy of International Law (Oxford: Oxford University Press)pp. 339-57.

Habermas, Jürgen (2010) "The Concept of Human Dignity and The Realistic Utopia of Human Rights," Metaphilosophy, Vol. 41, No. 4, pp. 464-80.

Hart, H. L. A. (1955) "Are There Any Natural Rights?" Philosophical Review, Vol. 64, No. 2, pp. 175-91.

Hart, H. L. A. (1994) The Concept of Law: Second Edition, with a Postscript edited by Penelope A. Bulloch and Joseph Raz (Oxford: Oxford University Press).

Hassoun, Nicole (2015) “The Human Right to Health," Philosophy Compass, Vol. 10, No. 4, pp. 275-83.

Hohfeld, Wesley (1923) Fundamental Legal Conceptions (New Haven: Yale University Press). James, Aaron (2005) "Constructing Justice for Existing Practice: Rawls and the Status Quo," Philosophy and Public Affairs, Vol. 33, No. 3, pp. 281-316.

Jones, Peter (1996) “International Human Rights: Philosophical or Political?” in Simon Caney, David George, and Peter Jones (eds), National Rights, International Obligations (Boulder, Colo.: Westview Press), pp. 183-204.

Lauterpacht, Hersch (1950) International Law and Human Rights (London: Stevens \& Sons). Reprinted in: Alston, Philip \& Goodman, Ryan (2013) International Human Rights (Oxford: Oxford University Press), pp. 150-7.

Letsas, George (2006) "Two Concepts of the Margin of Appreciation," Oxford Journal of Legal Studies, Vol. 26, No. 4, pp. 705-32.

Liao, S. Matthew (2015) The Right to be Loved (Oxford: Oxford University Press).

Liao, S. Matthew \& Etinson, Adam (2012) "Political and Naturalistic Conceptions of Human Rights: A False Polemic?” The Journal of Moral Philosophy, Vol. 9, No. 3, pp. 327-52.

Martin, Rex (1989) "Human Rights and Civil Rights" in Morton E. Winston (ed.), The Philosophy of Human Rights (Belmont: Wadsworth), pp. 75-85.

McGrath, Sarah (2008) "Moral Disagreement and Moral Expertise" in Oxford Studies in Metaethics, Volume 3 (Oxford: Oxford University Press), pp. 87-108.

Mill, John Stuart (1989) On Liberty and Other Writings, ed. Stefan Collini (Cambridge: Cambridge University Press).

Miller, David (2005) "Immigration: The Case for Limits" in Andrew I. Cohen and Christopher Heath Wellman (eds), Contemporary Debates in Applied Ethics (Malden, Mass.: Blackwell).

Moyn, Samuel (2015) "Human Rights and the Age of Inequality" in Doutje Lettinga \& Lars van Troost (eds), Can Human Rights Bring Social Justice? Twelve Essays (Amsterdam: Amnesty International Netherlands), pp. 13-19. 
Moyn, Samuel (2018) Not Enough: Human Rights in an Unequal World (Cambridge, Mass.: Harvard University Press).

Mutua, Makau (2002) Human Rights: A Political \& Cultural Critique (Philadelphia: University of Pennsylvania Press).

Neuman, Gerald (2003) "Human Rights and Constitutional Rights: Harmony and Dissonance," Stanford Law Review, Vol. 55, No. 5, pp. 1863-900.

Newman, Dwight (2011) Community and Collective Rights: A Theoretical Framework for Rights Held by Groups (Oxford: Hart Publishing).

Nickel, James W. (2006) "Are Human Rights Mainly Implemented by Intervention?" in Rex Martin \& David Reidy (eds), Rawls' Law of Peoples: A Realistic Utopia? (Oxford: Blackwell Publishing), pp. 263-78.

Nickel, James W. (2007) Making Sense of Human Rights: Second Edition (Oxford: Blackwell Publishing).

Nickel, James W. (2014) "Human Rights" in Edward Zalta (ed.), The Stanford Encyclopedia of Philosophy. Available online.

Nussbaum, Martha C. (2002) "Moral Expertise? Constitutional Narratives and Philosophical Argument," Metaphilosophy, Vol. 33, No. 5, pp. 502-20.

O’Neill, Onora (2005) “The Dark Side of Human Rights," International Affairs, Vol. 81, No. 2, pp. 427-39.

Posner, Eric A. (2014) The Twilight of Human Rights Law (Oxford: Oxford University Press).

Quong, Jonathan (2010) Liberalism Without Perfection (Oxford: Oxford University Press).

Rawls, John (1999) The Law of Peoples: With "The Idea of Public Reason Revisited" (Cambridge, Mass.: Harvard University Press).

Rawls, John (2005) Political Liberalism: Expanded Edition (New York: Columbia University Press).

Raz, Joseph (1998) "Disagreement in Politics," American Journal of Jurisprudence, Vol. 43, No. 1, pp. 25-52.

Raz, Joseph (2010) "Human Rights without Foundations" in John Tasioulas \& Samantha Besson (eds), The Philosophy of International Law (Oxford: Oxford University Press), pp. 321-39.

Raz, Joseph (2015) "Human Rights in the Emerging World Order" in Rowan Cruft, S. Matthew Liao, \& Massimo Renzo (eds), Philosophical Foundations of Human Rights (Oxford: Oxford University Press), pp. 217-32.

Risse, Mathias (2008) "On the Morality of Immigration," Ethics and International Affairs, Vol. 22, No. 1, pp. 25-33.

Risse, Mattias (2009) "A Right to Work? A Right to Leisure? Labour Rights as Human Rights," Law \& Ethics of Human Rights, Vol. 3, No. 1, pp. 1-39.

Sangiovanni, Andrea (2007) "Justice and the Priority of Politics to Morality", The Journal of Political Philosophy, Vol. 16, No. 2, pp. 2-28.

Sen, Amartya (2004) "Elements of a Theory of Human Rights," Philosophy and Public Affairs, Vol. 32, No. 4, pp. 315-56.

Shany, Yuval (2006) "Towards a General Margin of Appreciation Doctrine in International Law?" European Journal of International Law, Vol. 16, No. 5, pp. 907-40.

Shue, Henry (1996a) Basic Rights: Subsistence, Affluence, and U.S. Foreign Policy (Princeton: Princeton University Press) Second Edition.

Shue, Henry (1996b) “Thickening Convergence" in D. K. Chatterjee (ed.), The Ethics of Assistance: Morality and the Distant Needy (Cambridge: Cambridge University Press), pp. 226-7. 
Simmons, Beth (2009) Mobilizing for Human Rights: International Law in Domestic Politics (Cambridge, Mass.: Harvard University Press).

Singer, Peter (1972) "Moral Experts," Analysis, Vol. 32, No. 4, pp. 115-17.

Sinnott-Armstrong, Walter (1984) '“Ought' Conversationally Implies 'Can," The Philosophical Review, Vol. 93, No. 2, pp. 249-61.

Tadros, Victor (2015) "Rights and Security for Human Rights Sceptics" in Rowan Cruft, S. Matthew Liao, \& Massimo Renzo (eds), Philosophical Foundations of Human Rights (Oxford: Oxford University Press), pp. 442-58.

Tasioulas, John (2010) “Taking Rights out of Human Rights," Ethics, Vol. 120, No. 4, pp. 647-78.

Tasioulas, John (2012) “Towards a Philosophy of Human Rights," Current Legal Problems, Vol. 65, No. 1, pp. 1-30.

Taylor, Charles (1999) "Conditions of an Unforced Consensus on Human Rights" in J. R. Bauer \& D. A. Bell (eds), The East Asian Challenge to Human Rights (Cambridge: Cambridge University Press), pp. 124-47.

Valentini, Laura (2011a) "In What Sense Are Human Rights Political? A Preliminary Exploration," Political Studies, Vol. 60, No. 1, pp. 180-94.

Valentini, Laura (2011b) "Global Justice and Practice-dependence: Conventionalism, Institutionalism, Functionalism," Journal of Political Philosophy, Vol. 19, No. 4, pp. 399-418.

Valentini, Laura (2012) "Ideal vs. Non-ideal Theory: A Conceptual Map," Philosophy Compass, Vol. 7, No. 9, pp. 654-64.

Waldron, Jeremy (1993) Liberal Rights: Collected Papers 1981-1991 (Cambridge: Cambridge University Press).

Waldron, Jeremy (2012) Dignity, Rank and Rights (Oxford: Oxford University Press), ed. Meir Dan-Cohen.

Waldron, Jeremy (2013) "Political Political Theory: An Inaugural Lecture," The Journal of Political Philosophy, Vol. 21, No. 1, pp. 1-23.

Waldron, Jeremy (2015) "Is Dignity the Foundation of Human Rights?" in Rowan Cruft, S. Matthew Liao, \& Massimo Renzo (eds), Philosophical Foundations of Human Rights (Oxford: Oxford University Press), pp. 117-38.

Wellman, Carl (2011) The Moral Dimensions of Human Rights (Oxford: Oxford University Press).

Wenar, Leif (2005) "The Nature of Human Rights" in Andreas Follesdal \& Thomas Pogge (eds), Real World Justice: Grounds, Principles, Human Rights, and Social Institutions (Dordrecht: Springer), pp. 285-95.

Wilkins, Burleigh (2002) "International Human Rights and National Discretion," Journal of Ethics, Vol. 6, No. 1, pp. 373-82.

Williams, Bernard (2005) In The Beginning Was the Deed: Realism and Moralism in Political Argument (Princeton: Princeton University Press).

Wolff, Jonathan (2012) The Human Right to Health (New York: W.W. Norton \& Co.).

Yew, Lee Kwan (1992) "Democracy, Human Rights, and the Realities." Speech delivered at the creation of the Asahi Forum, Tokyo, 20 November 1992.

Zolo, Daniel (2010) “Humanitarian Militarism?” in Samantha Besson \& John Tasioulas (eds), The Philosophy of International Law (Oxford: Oxford University Press), pp. 549-69. 